FACULTY OF BUSINESS ADMINISTRATION AND ECONOMICS

Working Paper Series

Working Paper No. 2019-08

The relationship between announcements of complete mergers and acquisitions and acquirers' abnormal CDS spread changes

Benjamin Hippert

August 2019 


\title{
The relationship between announcements of complete mergers and acquisitions and acquirers' abnormal CDS spread changes*
}

\author{
Benjamin Hippert ${ }^{\dagger}$
}

\begin{abstract}
Employing a sample of 492 merger and acquisition (M\&A) announcements from 284 acquirers across North America and Europe between 2005 and 2018, this study analyzes the impact of M\&A announcements on an acquirers abnormal CDS spread changes. We find that spreads from CDS which are written on acquirers increase by 310 bps during a symmetric five-day event window suggesting that investors expect an increase in the acquirers credit risk exposure due to M\&As. Next to this baseline finding, we conduct a large variety of sensitivity analyses to gain more insight into the driving factors of the rising risk perception of CDS investors due to M\&A announcements.
\end{abstract}

Keywords: credit default swaps, risk perception of CDS investors, mergers and acquisitions, event study

JEL Classification: G14, G34

*I am grateful to André Uhde, Sascha Tobias Wengerek, Sonja Warkulat, and Matthias Pelster for their helpful comments and discussions. Finally, I thank Maike Daniel, Sarah Herwald and Marcel Lengacher for outstanding research assistance.

†University of Paderborn, Warburger Straße 100, 33098 Paderborn, Germany, phone: +49 5251 605550, fax: +49 5251 604207, e-mail: benjamin.hippert@upb.de. 


\section{Introduction}

Mergers and acquisitions (M\&As) are still significant popular instruments for achieving corporate growth and diversification. As shown by Figure 1, M\&As almost continuously increase in numbers and transaction volumes since 1985. Accordingly, the number of transactions reached its peak in 2017 with 52,213 worldwide M\&A deals, while the volume of M\&A deals exhibited its maximum in 2007. Figure 1 further reports a sharp increase at the end of the 1990s and in the mid 2000s, which are both followed by a sudden drop due to the dotcom crisis in the early 2000s and the global financial crisis in 2007/2008. By now, especially the North American market has recovered to pre-crises numbers and volumes. In contrast, the European market remained fairly stable after the global financial crises in terms of numbers of M\&As, but has remarkably decreased in terms of values and is still struggling due to the European sovereign debt crises.

The academic literature identifies several reasons to engage in M\&As. Thus, firms may have efficiency gains from increased economies of scale and scope, cash flow diversification which improves their solvency in times of volatile markets as well as strategic gains from an improved competitive position (Ismailescu and Col, 2016). However, M\&A transactions are not riskless. As demonstrated by Bruner (2002) and Christensen et al. (2011), about $70 \%$ of M\&A transactions do not pay off, i.e. the transaction does not create a material and significant (abnormal) value. Taking this into account, the study at hand empirically analyzes if acquiring another company may change the risk perceptions of those investors who hold credit default swaps (CDSs) that are written on the acquring company.

The research on announcements of M\&As has primarily focused on shareholder's perceptions (see e.g., Malatesta, 1983; Doukas and Travlos, 1988; Franks and Harris, 1989; Goergen and Renneboog, 2004), whereas there is less research that focuses on the aspect if the risk perception of an acquirer's CDS investor changes with respect to an announcement of an M\&A transaction. The theoretical literature suggests that acquirers exhibit significantly reduced risks, a higher debt capacity and an increased borrowing ability if earnings streams of the merging firms are less than perfectly correlated, which is known as the coinsurance effect (Levy and Sarnat, 1970; Lewellen, 1971; Higgins and 
Schall, 1975; Kim and McConnell, 1977). In this context, Shastri (1990) and da Silva et al. (2015) stress that it depends on the specific fundamental characteristics of the target and acquirer (e.g., risk level, leverage ratio, debt maturities) if merging firms may benefit from coinsurance effects, or may even lose from expropriation effects. Moreover, debtholders may also benefit from a reduced probability of default if merging firms have not perfectly correlated assets. In this context, Amihud and Lev (1981) state that "a conglomerate merger generally leads, through the diversification effect, to reduced risk for the combined entity". In contrast, however, Furfine and Rosen (2011) provide empirical evidence that the acquirer's default risk may increase if the target firm exhibits a worse credit rating and if this additional risk is transferred to the acquirer. In addition, the acquirer's default risk may also rise if the acquirer's financial leverage increases due to the merger. In this context, Leland (2007) shows that an acquirer's leverage may rise after a merger, but that the probablity of default may decrease if the positive effects (diversification, tax shield provided by debt, recapturing wealth from bondholders) outweigh the risk from an increased financial leverage. Against this background, the impact of an M\&A transaction on the acquirer's default risk and hence, on the risk-perception of the acquirer's CDS investors is still puzzling.

The study at hand contributes to the existing literature by focusing on changes in the CDS investors' risk perceptions due to the announcement of M\&A transactions as follows: In contrast to the majority of previous research papers, we investigate changes in CDS spreads instead of changes in bond returns. Analyzing CDS spread changes has several advantages as compared to bonds. Given that the CDS market may be an alternative trading venue for debtholders (Bessembinder et al., 2008; Oehmke and Zawadowski, 2016), CDS spreads may be a more appropriate measure for investors' perceptions of a firm's risk exposure due to the following reasons. To begin with, CDSs are more liquid and therefore, changes in CDS spreads may better reflect the changes in invesors' perceptions of firm risk as compared to bonds. Furthermore, contract maturities are standardized making it more convenient to compare CDS spreads across firms. In addition, instead of aggregating returns across several bonds with potentially different liquidity and trading intensities, 
only one security per issuing firm needs to be evaluated in case of CDSs. Moreover, the CDS spread is a market-based measure of default risk, which can directly be observed and traded by investors to hedge their debt or equity position according to their risk perceptions (Greatrex, 2009; Longstaff et al., 2011). ${ }^{1}$ Finally, in contrast to other default risk measures that try to capture the long term risks (like ratings), CDS spread changes reflect the investors' risk perceptions immediately. Accordingly, the CDS spread change may be a more precise measure of an investor's perception of a firms default risk.

The empirical literature that measures a change in the investors risk perception due to announcements of M\&A transactions by means of changes in CDS spreads is scarce. Analyzing 95 and 3,568 M\&A transactions, respectively, Hraschek et al. (2016) and da Silva et al. (2015) show that the CDS market participants may anticipate M\&A announcements via insider trading of CDS from banks that take part in the deals. They additionally find that this effect is even stronger when investment banks are involved. Furthermore, da Silva et al. (2015) show that the CDS market may even have more predictive power than the stock market shortly before takeover announcements. Ismailescu and Col (2016) focus on the credit risk perception of CDS investors during cross-border acquisition announcements of U.S. firms by analyzing abnormal CDS spread changes. Analyzing 889 acquisitions, they find an average increase in investors' credit risk perception when the target firm is located in an emerging market, and they observe a decrease when the target firm is located in a developed country.

Most related to our analysis, Hüttermann and Lleshaj (2018) investigate debtholder wealth effects through CDS spreads by analyzing a worldwide sample of 3,255 M\&A transactions. Referring to debtholders as CDS investors, they find a negative effect of a takeover on an acquirering firm's debtholder wealth measured by abnormal CDS spread changes. Even though the research design is similar to ours, their event study framework has some limitations. Hüttermann and Lleshaj (2018) only conduct a simple cross sectional t-test without accounting for cross-sectional correlation, event-induced

\footnotetext{
${ }^{1}$ However, most of the studies, which focus on the measurement of the acquirer's default risk, employ Merton's theoretically derived, and thus, not directly observable, distance to default model (e.g., Furfine and Rosen, 2011; Vallascas and Hagendorff, 2011).
} 
volatility and serial correlation, which may heavily bias the results, especially in times of high market volatility during financial crises (Cathcart et al., 2013). In contrast, the study at hand employs a $\operatorname{GARCH}(1,1)$ model to account for volatility clustering and conditional heteroskedasticity of the CDS spread changes (see e.g. Farruggio et al., 2013). Furthermore, while Hüttermann and Lleshaj (2018) use a constant mean model to calculate the market's CDS spread change, we employ a four-factor model since this model proxies the CDS investor's risk perception of the market more adequately (Andres et al., 2016). In addition, we implement different model inputs, which depend on the rating category of the analyzed entity. Finally, we are able to analyze cross-border and domestic takeovers simultaneously. This is due to the fact, that (as compared to a partial $\mathrm{M} \& \mathrm{~A})$ the target firm does not remain an entity under the jurisdiction of its head office's country and the acquirer is not additionally exposed to a country specific risk factor (Bris and Cabolis, 2008; Ismailescu and Col, 2016).

The empirical study at hand employs a sample of 492 complete M\&A transactions from 284 acquirers across North America and Europe between 2005 and 2018. Our analysis initially reveals that acquiring firms exhibit positive abnormal CDS spread changes of about 310 bps during a five-day event window due to the announcement of a complete M\&A transaction. This result suggests that investors in CDSs, which are written on the acquirer, perceive an increase in the acquirer's credit risk exposure immediately after the announcement has taken place. In contrast, we do not find that CDS investors anticipate the transaction risk before the announcement. Rather, we observe the highest abnormal CDS spread at the announcement day and a fading of this effect during the next two trading days. These baseline findings hold even when varying the event window length and under a variety of robustness tests. Moreover, results from further sensitivity analyses, i.e. splitting the sample in different deal, acquirer and target characteristics, provide further important insights into the CDS inverstors' risk perception due to M\&A announcements.

The remainder of the paper is organized as follows. Section 2 presents the empirical methodology and Section 3 introduces the data. While Section 4.1 presents the empirical results from the baseline analysis, Section 4.2 introduces the tests for the robustness of 
our results. Section 4.3 discusses the results from the sensitivity analyses and finally, Section 5 summarizes and concludes.

\section{Empirical methodology}

Following Brown and Warner (1985), we employ a standard event study methodology in order to analyze abnormal CDS spread changes due to M\&A announcements from North American and European listed acquiring firms between May 2005 and October 2018. ${ }^{2}$ According to the efficient market hypothesis proposed by Fama (1970), CDS spreads should reflect all publicly available information in the market and hence, should adjust when new public information is provided if, at least, the semi-strong efficiency is assumed.

The change in an acquiring firm's credit risk exposure during an event window is measured by the acquirer's CDS spread change. Let $t_{0}$ be the date of the event, then an event window starting at $t_{-1}$ and ending at $t_{1}$ is set such that $t_{-1} \leq t_{0} \leq t_{1}$ holds and $\left[t_{-1}, t_{1}\right]$ represents the event window. The CDS spread changes $\left(\Delta C D S_{i, t}\right)$ for each firm $i$ and time $t$ are calculated as

$$
\Delta C D S_{i, t}=\ln \left(\frac{C D S_{i, t}}{C D S_{i, t-1}}\right)
$$

We fit the $\triangle C D S_{i, t}$ time series with a $\operatorname{GARCH}(1,1)$ model to account for volatility clustering and autoregressive conditional heteroskedasticity.

Subsequently, following MacKinlay (1997), the abnormal CDS spread change $\left(A C S C_{i, t}\right)$ is calculated as the difference between the realized CDS spread change $\left(\Delta C D S_{i, t}\right)$ and the expected CDS spread change $\left(E\left[\Delta C D S_{i, t}\right)\right.$ in absence of the event at time $t_{0}$ :

$$
A C S C_{i, t}=\Delta C D S_{i, t}-E\left[\Delta C D S_{i, t}\right] .
$$

\footnotetext{
${ }^{2}$ The sample period starts in May 2005 since trading data on CDS indices are not available before December 2004. In addition, a data time series of 6 months is necessary to perform the event study.
} 
In line with Andres et al. (2016), expected CDS spread changes are calculated by employing a four-factor market model approach. ${ }^{3}$ The four factors utilized are (i) the CDS market index, (ii) the level of the risk-free yield curve, (iii) the slope of the risk-free yield curve and (iv) the equity implied volatility. ${ }^{4}$ Accordingly, the expected CDS spread change can be calculated as

$$
E\left[\Delta C D S_{i, t}\right]=\alpha_{i}+\beta_{i} \Delta \text { Index }_{m, r, t}+\gamma_{i} \Delta Y C_{m, t}+\delta_{i} \Delta \text { SlopeY }_{m, t}+\epsilon_{i} \Delta \text { Vola }_{m, t},
$$

where $\alpha_{i}, \beta_{i}, \gamma_{i}, \delta_{i}, \epsilon_{i}$ are estimated for each firm by the ordinary least squares (OLS) method with an estimation window starting at $t_{-3}$ and ending at $t_{-2}$, where $t_{-3}<t_{-2}<$ $t_{-1}$ holds. Hence, the estimation window is represented by $\left[t_{-3}, t_{-2}\right] . \Delta \operatorname{Index}_{m, r, t}$ is the CDS spread change of the CDS market index in rating category $r, \Delta Y C_{m, t}$ is the change of the yield curve with a maturity of 5 years, $\Delta$ Slope $Y C_{m, t}$ is the change of the slope of the yield curve and $\Delta V$ ola $_{m, t}$ is the change of the equity implied volatility of market $m$ at time $t$. The cumulative abnormal CDS spread changes for a single event are then calculated as

$$
C A C S C_{i,\left[t_{-1}, t_{1}\right]}=\sum_{t=t_{-1}}^{t_{1}} A C S C_{i, t},
$$

where $C A C S C_{i,\left[t_{-1}, t_{1}\right]}$ is the cumulative abnormal CDS spread change of firm $i$ during the event window $\left[t_{-1}, t_{1}\right]$.

\footnotetext{
${ }^{3}$ During further analyses, we control for the robustness of our results by implementing both, a onefactor model and a constant mean model.

${ }^{4}$ As regards the market index, we use the CDX North American Investment Grade Index for North American investment grade entities and the CDX North American High Yield Index for entities that exhibit non-investment grade ratings. We employ the iTraxx Europe for firms with investment grade rating and the iTraxx Europe High Volatility for non-investment grade firms as corresponding indices for Europe. All CDS indices are provided by Markit. If we do not observe a rating for an entity, we use the CDS implied rating as a proxy (Jansen and Fabozzi, 2017). The level of the risk-free yield curve is proxied by the interest rate with a 5-year maturity and is retrieved from the US Department of the Treasury for North America and from the European Central Bank for Europe. The slope of the yield curve is calculated as the difference of the 10-year and 1-year yields. Finally, the equity implied volatility is measured by the VIX and VSTOXX for North America and Europe, respectively. The volatility indices are retrieved from Thomson Reuters Datastream.
} 
When considering multiple events the (cumulative) average abnormal CDS spread changes are calculated as

$$
\begin{aligned}
A A C S C_{t} & =\frac{1}{N} \sum_{i=1}^{N} A C S C_{i, t}, \\
C A A C S C_{\left[t_{-1}, t_{1}\right]} & =\sum_{t=t_{-1}}^{t_{1}} A A C S C_{t},
\end{aligned}
$$

where $A A C S C_{t}$ is the average abnormal CDS spread change of all firms $N$ at time $t$ and $C A A C S C_{\left[t_{-1}, t_{1}\right]}$ is the cumulative average abnormal CDS spread change during the event window $\left[t_{-1}, t_{1}\right]$. We use an estimation window of 100 days for our baseline analysis. We set the estimation window to $[-120,-21]$ and the main event window to $[-2,2] .{ }^{5}$

The impact of M\&A announcements on the acquiring firms' abnormal CDS spread changes is tested with two different non-parametric tests. We use non-parametric tests since they are more effective in small sample sizes and when assuming a nonnormal distribution of CDS spread changes. Moreover, non-parametric tests tend to dominate parametric tests and therefore, should be preferred in event studies of abnormal security price performance (Kolari and Pynnonen, 2011). We initially implement the Wilcoxon-signed-rank test (henceforth Wilcoxon test) since this test accounts for both, the importance of the sign and the magnitude of the changes in (cumulative) abnormal CDS spread changes. In addition, this test has a power advantage over t-tests for fattailed distributions (Wilcoxon, 1945; Corrado, 1989). As a second test, we employ the generalized rank test (GRANK test) as proposed by Kolari and Pynnonen (2011). This test extends the single day non-parametric test of Corrado and Zivney (1992) to an efficient testing of cumulative abnormal changes. Furthermore, the GRANK test is robust to serial correlation in CDS spread changes, event-induced volatility and cross-sectional correlation of CDS spread changes due to event day clustering. In addition, Kolari and Pynnonen (2011) show that the GRANK test exhibits superior empirical power as compared to

\footnotetext{
${ }^{5}$ We also analyze the following different variations of the event window: $[-2,1],[-2,0],[-1,2],[0,2]$, $[-1,1],[-1,0],[0,1],[-5,5]$ and $[-10,10]$. Furthermore, during robustness checks in Section 4.2.3, we change the estimation window to 60 and 200 days. We also implement the model without a gap between the estimation and event windows.
} 
popular parametric tests (e.g., Patell, 1976 or Boehmer et al., 1991) for all event window lengths. ${ }^{6}$

\section{Data}

We retrieve M\&A data from Thomson Reuters' Security Data Corporation database (SDC). This database includes information about the acquiring and target firms as well as several deal characteristics. We initially collect data on all takeovers in North America and Europe between May 2005 and October 2018. Following Masulis et al. (2007) and Harford et al. (2012), we only employ data on completed M\&A transactions when the bidder owns less than $50 \%$ of the target before the acquisition and $100 \%$ after the deal (full transfer of control rights). In addition, the transaction value must exceed $\$ 1$ million or $1 \%$ of the bidder's net assets 11 days prior to the announcement date. Furthermore, to avoid a bias from confounding events, we consider only the first M\&A announcement if we observe more than one announcement by the same acquirer within three months. Finally, if an event is announced on a weekend or holiday, we define the next Monday or the day after the holiday as the announcement day.

Daily CDS spread data is retrieved from IHS Markit (Markit), the leading vendor of credit pricing data. We only consider CDS spreads with a five-year maturity since these are the most liquid contracts in the CDS market. Additionally, we focus on CDS that are written on senior unsecured debt to avoid any bias due to differences in seniority. CDS on North American entities follow the documentation clause modified restructuring (MR) and are denominated in USD, while the CDS on European entities follow the modified

\footnotetext{
${ }^{6}$ Note that the GRANK statistic is based on the standardized (cumulative) abnormal CDS spread changes which are defined as

$$
\begin{aligned}
S A C S C_{i, t} & =\frac{A C S C_{i, t}}{S_{A C S C_{i, t}}} \\
\text { and } S C A C S C_{i,\left[t_{-1}, t_{1}\right]} & =\frac{C A C S C_{i,\left[t_{-1}, t_{1}\right]}}{S_{C A C S C_{i,\left[t_{-1}, t_{1}\right]}}}
\end{aligned}
$$

where $S_{A C S C_{i, t}}$ and $S_{C A C S C_{i,\left[t_{-1}, t_{1}\right]}}$ are the standard deviations of the regression prediction errors in the (cumulative) abnormal CDS spread changes following Campbell et al. (1997).
} 
modified restructuring clause (MM) with denomination in EUR (Andres et al., 2016; Augustin et al., 2016; Jansen and Fabozzi, 2017).

The two databases are merged by retaining acquirers which exhibit at least 6 months of CDS data prior and 1 month after the announcement date. ${ }^{7}$ We exclude those acquiring firms with missing CDS spreads or without trading activities on more than five consecutive trading days during the estimation window. In addition, all acquirers with missing CDS spreads on the event day and less than $90 \%$ of non-missing CDS data in the event window are excluded as well. This yields to a final sample of 492 transactions from 284 different acquirers. Respective balance sheet and market data for these acquirers is retrieved from Thomson Reuters Datastream and EIKON.

As shown by Table 1, the total number of acquisition announcements in our sample peaks in 2006 and 2007, remains stable from 2008 to 2014 and decreases since 2015. This development is mainly driven by the European M\&A market, which exhibits a similar number of announcements as compared to the North American market in the years 2005 and 2006, whereas the number of announcements remarkably decreases after the global financial crisis and does not recover as fast as on the North American market. Furthermore, Table 1 reveals that nearly $65 \%$ of the acquirers in our sample are located in North America. Likewise, Table 2 indicates that the majority of all acquirers originate in the United States, while France and the United Kingdom follow at a huge distance. The distribution of the acquirers over the 10 sectors as defined by Markit are mapped in Table 3 (by region) and in Table 4 (by year). As shown, the industrial sector comprises the highest number of transaction announcements in both Europe and North America, whereas 'utilities' describes the group with the fewest announcements in total. However, the energy sector exhibits the lowest number of announcements in Europe, while 'Telecommunications Services' is the group with the lowest announcements in North America. Table 5 reports the number of acquisition announcements by target firms' home countries and acquirer firms' regions. As illustrated, 50\% of all European acquisitions are made outside of Europe, whereas only about $20 \%$ of the targets of North American

\footnotetext{
${ }^{7}$ As mentioned above, we require 5 months of CDS data for the estimation window and 1 month of CDS data for the gap between the estimation and event window to perform the analysis.
} 
companies are located outside of North America. This underrepresentation of US firms in cross-border M\&As is well-established in the literature (see e.g., Erel et al., 2012). Table 6 and Table 7 map the Markit sector of the acquisition announcements by the acquirers' regions and by year, respectively. The tables reveal that, in total, most acquisitions are made in the technology sector followed by the healthcare sector, whereas the fewest takeovers are observed for the utility sector. This result is mainly driven by the North American market, which also exhibits the highest number of takeover announcements in the technology sector and the fewest in the utility sector. However, the European market draws a different picture since the most transaction announcements are observed in the industrial sector and the fewest in the energy sector.

Table 9 presents deal, acquirer and target characteristics for the 492 acquisition announcements in our sample. The respective variables are described in Table 8. As initially shown, in case of $75 \%$ of the deals the acquirer does not diversify its business model by means of the transaction, but rather performs a horizontal M\&A transaction. Furthermore, as our sample includes only complete transactions, the most deals are mergers while the remaining $16 \%$ include acquisitions of assets. It is also revealed that, nearly half of the deals are cross-border transactions and have, on average, a transaction volume of $\$ 4.4$ billion. The average acquirer in our sample is a large firm with $\$ 63.6$ billion in total assets and a leverage ratio of $136 \%$. In addition, the market-to-book value being greater than one indicates that the acquiring firms are overvalued. Moreover, the preannouncement mean CDS spread is about 103 basis points and the average rating of an acquirer is between A3/A- (Moody's/S\&P and Fitch) and Baa1/BBB+. In contrast, the average acquired company exhibits $\$ 5.7$ billion in total assets and thus, is much smaller than the acquirers. However, the target firms' leverage ratio and the market-to-book value are, on average, similar to those of the acquirers. Moreover, the average rating of a target is between Baa3/BBB- (Moody's/S\&P and Fitch) and Ba1/BB+. However, only approximately $25 \%$ of all targets have a rating from the three major rating agencies. Finally, about $80 \%$ of the targets are publicly listed companies. 
Table 10 reports the deal, acquirer and target characteristics for the respective two analyzed regions, i.e. 319 North American and 173 European M\&A transaction announcements, individually. As initially shown, one third of the European acquiring firms take over in another sector ('Diversification'), nearly $85 \%$ of all European transactions in our sample are mergers and over $80 \%$ of the transactions are cross-border M\&A transactions. In contrast, the North American acquirers are less diversified (20\%) and buy predominantly inside the North American market (80\%) while the ratio of mergers is again at $85 \%$. The absolute 'Transaction volume' is larger in Europe, however, the 'Transaction volume ratio' and the 'Size ratio' indicate that the deal or target firm's size in relation to the acquirer's size is larger in North America. Hence, the acquiring firms in Europe are, on average, larger in size ('Total Assets') and buy smaller firms as compared to the North American acquirers. As regards the 'Leverage ratio', Table 10 shows that the North American acquirers are stronger levered, but buy less levered firms as indicated by the ratio 'Lower leverage than target', although the leverage ratios of the target firms are very similar. In addition, the 'Leverage change' between the pre- and post-announcement is positive for both, North American and European acquirers, but larger for North American acquiring firms. The acquirers' 'Market-to-book value' is, on average, greater than one for both regions, however, the ratio is almost two times higher for North American acquirers. As regards credit risks, it can be observed that European acquiring firms exhibit a better rating by one notch and also take over better rated firms ('Rating'). In addition, 'Rated' indicates that only $28 \%$ of North American and $18 \%$ of European target firms are rated by at least one of the three largest rating agencies. The better rating of European acquirers is also reflected in the 'Mean CDS spread' since the CDS protection sellers demand a smaller premium for European acquirers. Next, 'Regulation' indicates that the relation of high-regulated to unregulated acquirers in the North American and the European sample is similar. Finally, the proportion of publicly listed target firms is similar for the North American and European M\&A market in our sample. 


\section{Empirical results}

We provide results from our baseline analysis in Table 11 and Figure 3. While results from robustness checks are provided in Tables 10, 12 and 13, results from sensitivity analyses are shown in Tables 14 to 16.

\subsection{Baseline analysis}

Results from Table 11 suggest that the announcement of a complete M\&A transaction is, in general, a surprising effect, although the CDS market is frequently used by insiders (Acharya and Johnson, 2007). In contrast to da Silva et al. (2015) and Hraschek et al. (2016), we do not find a statistically significant anticipation of M\&A transaction announcements due to insider trading in the CDS market. Rather, we find a high and significant average abnormal CDS spread change (AACSC) at the day of the M\&A announcement. Since the CDS market is not strong-form efficient in the sense of Fama (1970), the effect of the announcement is not immediately and completely perceived by CDS investors but can be observed two more trading days until it is completely processed. ${ }^{8}$ Both, the Wilcoxon and the GRANK test indicate that the average abnormal CDS spread changes significantly increase by approximately 165 bps, 95 bps and 29 bps at the announcement day and the two following days, respectively. It is also observed that the AACSCs exhibit the highest proportion of approximately $58 \%$ of positive values at the announcement day. In fact, this ratio indicates that the majority of the CDSs, which are written on the acquirers, exhibit positive abnormal spread changes and hence, that the results are not biased by a few outliers.

As regards the cumulative average abnormal CDS spread changes, we find positive and significant results throughout all variations of the event window. The proportion of positive CAACSCs is also significantly higher than $50 \%$ in all analyzed event windows. Thus, this ratio suggests that the CAACSCs are not skewed by only a few observations. However, as also shown, the GRANK test points to decreasing effects for longer event

\footnotetext{
${ }^{8}$ We additionally employ longer event windows of up to 20 days before and after the event. However, since our results remain qualitatively unchanged, we do not report them in this paper.
} 
windows of 11 and 21 days. Generally, an acquirers' CAACSC increases by about $272 \mathrm{bps} / 310 \mathrm{bps} / 365 \mathrm{bps} / 378 \mathrm{bps}$ in a symmetric 3/5/11/21-days event window. The development of the CAACSCs of our [-2,2] main event window is illustrated in Figure 3. As regards Table 11 and Figure 3, we observe that the CAACSC initially increases moderately (but insignificantly) during the days before the announcement and increases significantly by about 289 bps at the announcement day and the following two days.

Against this background, our baseline findings do not support theoretical arguments suggesting that CDS investors may value an M\&A deal as less risky (or riskless) due to probable coinsurance effects (Levy and Sarnat, 1970; Lewellen, 1971; Higgins and Schall, 1975). In contrast, as we find a positive change of CDS spreads due to an M\&A announcement, our result suggests that CDS investors expect an increase in the acquirers risk exposure and probability of default which may be due to a potential transfer of risk from the target to the acquirer, an increase of the acquirer's leverage ratio or a decrease of its distance to the default (Dennis and McConnell, 1986; Shastri, 1990; Billett et al., 2004; Bessembinder et al., 2008; Furfine and Rosen, 2011; da Silva et al., 2015).

\subsection{Robustness checks}

We provide several tests to control for the robustness of our baseline results. Respective results are reported in Tables 12 and 13.

\subsubsection{Sector analysis}

To begin with, we control if M\&A announcements within different industrial sectors are perceived differently by CDS investors. To be upfront with it, results from this analysis must be taken with caution since the number of observations for each sector is small. Table 12 initially reports that we observe the highest CAACSCs for the sectors of consumer goods (781 bps) and basic materials (563 bps), while the lowest but still positive statistical significant change is found for the technology sector (191 bps). Turning to the sectors of the target firms, we again observe the highest CAACSCs when M\&As take place in the sectors of consumer goods (737 bps) and basic materials (868 bps). However, it is 
also revealed that M\&As in the sector of telecommunication services exhibit the lowest statisitcal significant CAACSCs (152 bps). Overall, investors in CDSs, which are written on acquiring firms perceive the greatest risk increase due to M\&A announcements in the sector of consumer goods and basic materials. This finding is irrespective of whether the acquiring firm belongs to these sectors or buys in these sectors.

\subsubsection{Regional differences}

As shown in Table 10, our sample is dominated by North American acquirers (65\% of our sample) and the M\&A characteristics of these two markets exhibit several differences (see Section 3), we rule out that our results are biased due to the sample construction. As reported by Table 13, we show that both, the European and the North American subsample, exhibit positive and statistical significant CAACSCs. However, the difference in CAACSCs between these subsamples and our baseline result is small and statistically insignificant. ${ }^{9}$ Therefore, as we do not find statistical significant differences between the two subsamples and between the subsamples and our baseline analysis, we rule out that our sample is biased due to the higher number of North American acquirers.

\subsubsection{Robustness of the model}

First, to control for the robustness of our empirical design, we investigate if our results are biased due to the specification of the market model. We substitute the four-factor model approach by a standard market model approach with the CDS market index as the only factor and a constant mean model. As shown by Table 13, the difference between our baseline approach and the market model (constant mean model) amounts to -2.0272 bps (14.2082 bps). However, since both difference values are insignificant it is indicated that our results are robust when employing other model specifications.

Second, we are aware of the fact that the choice of the event window length is, to some extent, arbitrary. In addition, the event window length may bias the results. Hence, longer windows may smooth the prediction of the CDS spread changes, whereas shorter

\footnotetext{
${ }^{9}$ In addition, in an unreported analysis, we evaluate the difference of 20.7965 bps between the European and the North American subsample and do not find that this difference is significant.
} 
windows may not predict the CDS change adequately since smaller windows are more prone to outliers. Taking this into account, we choose two different settings (200 days and 60 days) for the estimation of the abnormal CDS spread changes. As reported by Table 13, our results are qualitatively reiterated even when implementing a shorter 60days and a longer 200-days estimation window.

Third, the gap between the estimation and event window, as modeled in our main analysis, may potentially bias our results since the model does not process the changes in CDS spreads directly before the event window. To address this issue, we modify our estimation strategy and let the event window follow the estimation window immediately. As shown by Table 13, we do not observe a significant difference between the implementation with and without a gap. Therefore, we can rule out that the gap between the estimation and event window may bias our baseline results.

Finally, we simplify our market model approach. We do not distinguish between investment grade and speculative grade rating categories in our market model since the high yield indices may bias the results due to lower liquidity as compared to the investment grade indices, which are the most liquid in the CDS market. Taking this into account, we employ the main investment grade CDS indices in the corresponding markets, namely the CDX North American Investment Grade Index for all North American acquirers and the iTraxx Europe for all European acquirers, regardless of their rating. As shown in Table 13, however, the results are qualitatively reiterated even when employing the main investment grade CDS indices.

\subsection{Sensitivity analysis}

To shed a brighter light on our baseline findings that investors in CDS perceive a higher risk exposure of acquiring firms due to an M\&A announcement, we perform a large variety of sensitivity analyses. During these analyses we refer to the CAACSC of the $[-2,2]$ main event window as discussed in Section 4.1.10

\footnotetext{
${ }^{10} \mathrm{We}$ also perform these analyses by referring to CAACSC from the $[-1,1]$ event window. However, since the results are qualitatively reiterated, we provide them on request.
} 


\subsubsection{Deal characteristics}

We start by investigating if different deal characteristics may have an impact on the risk perception of investors who hold CDSs which are written on acquiring firms.

Diversification We suggest that cross-sectional M\&A transactions may reduce acquirer CDS spreads due to diversification effects, an increasing operating efficiency and debt capacity as well as a probable decrease of the tax burden (Lewellen, 1971; Hann et al., 2013; Kuppuswamy and Villalonga, 2015; Ismailescu and Col, 2016). However, crosssectional takeovers may also have a negative impact on the acquiring firm's risk exposure. Hence, acquirers may have to deal with exacerbating agency problems between corporate insiders and small shareholders due to adverse implications on the market value of the conglomerate (Laeven and Levine, 2007) as well as with higher costs from information asymmetries between the central management and divisional managers (Myerson, 1982; Harris et al., 1982). ${ }^{11}$ Jensen (1986) and Stulz (1990) additionally argue that diversified firms will perform more projects with a negative net present value as poor business segments in diversified firms have access to free cashflows, which would not be the case if they were operated independently. Similarly, Meyer et al. (1992) suggest that a failing business cannot have a negative value, but poor business segments may have negative contributions in a diversified conglomerate that provides cross-subsidies which increases the conglomerate's risk exposure. Thus, the impact of a cross-sectional M\&A transaction on the acquirer's credit risk exposure and hence, the acquirer CDS spread, is ambiguous.

As reported by Panel A in Table 14, we provide empirical evidence that both, an announcement of a diversified merger and of a takeover within the same business category lead to CDS investors who perceive that the resulting conglomerate may be more risky as measured by the five-days CAACSCs. However, as also shown, we do not find a significant difference between these subsamples. Accordingly, a diversified transaction is perceived by CDS investors in our sample to be as risky as a horizontal M\&A transaction.

\footnotetext{
${ }^{11}$ Previous research has shown that conglomerates have problems in designing efficient managerial incentive contracts and in aligning the incentives of outsiders and insiders (Aron, 1988; Stulz, 1990; Rotemberg and Saloner, 1994).
} 
Type of transaction In our sample, takeovers include mergers as well as acquisition of assets in tender offers. In both transaction types the bidding firm offers to buy stocks of the target at a price in excess of the target's market value. However, while mergers are negotiated directly between the managers of both firms and are approved by the target's board of directors before the vote of the target's shareholders, the bidding firm buys the shares directly from the target's shareholders who decide individually whether to sell or not during an acquisition of assets in tender offers (Jensen and Ruback, 1983). Numerous studies have examined whether different transaction types increase or decrease the shareholder value of bidding firms. These studies provide empirical evidence that acquiring firms earn negative abnormal stock returns from mergers and little or no abnormal stock returns from acquisitions through tender offers (Dodd and Ruback, 1977; Dodd, 1980; Asquith, 1983; Jensen and Ruback, 1983; Bradley et al., 1988; Agrawal et al., 1992; Rau and Vermaelen, 1998). Furthermore, Avinadav et al. (2017) analyze the impact of risk-averse bidding firms and takeover outcomes. They argue that mergers lead to higher payoffs than acquisitions when the parties are risk-averse. In addition, they propose that acquisitions might even be non-beneficial depending on the risk-aversion of the involved parties. Moreover, referring to the effects of different transaction types on an investor's credit risk perception, Billett et al. (2004) report that acquirers' excess bond returns are significantly lower in tender offers as compared to mergers, which is in line with the theoretical predictions by Avinadav et al. (2017).

As reported by Panel B in Table 14, we find that mergers significantly increase the CAACSCs by 347 bps during the $[-2,2]$ window while we do not find a significant impact on CAACSCs due to the acquisition of assets. In addition, the difference of 234 bps between the transaction types is statistically significant, indicating that investors perceive the merger as more risky than it is during acquisitions of assets through tender offers. This finding is in line with the predictions from the empirical literature arguing that investors perceive higher risks due to the underperformance of acquiring firms following a merger.

Cross-border Cross-border M\&As may generate additional risks as compared to domestic mergers. For instance, acquirers in cross-border transactions have to overcome 
cultural and geographical distances, which increase the takeover costs and decrease the probability of a transaction (Rose et al., 2000). Furthermore, these aspects exacerbate the integration process of the foreign target firm, which may result in additional costs and inefficiency due to higher coordination needs, a stronger monitoring and controlling of the departments and conflicts between fragmented interests of specialized departments (Shrivastava, 1986). ${ }^{12}$ In contrast, the acquiring firm may benefit from the entrance in a foreign market if the market share is increased, new business opportunities are created and the business model is better diversified (Francis et al., 2008; Erel et al., 2012). In this context it is found that the positive effects are even stronger when acquirers from developed countries perform takeovers in emerging markets due to better institutional and corporate governance practices of the acquirer (Ismailescu and Col, 2016).

As pointed out by Panel $\mathrm{C}$ in Table 14, we find a positive and significant increase in CAACSCs for cross-border transactions, which is in line with the arguments provided by Rose et al. (2000) and Shrivastava (1986). However, we also note a significant increase in CAACSCs for domestic mergers, while the difference between the increase in CAACSCs in cross-border and domestic M\&As is not statistically significant. Hence, CDS investors of acquiring firms expect a similar increase of the acquirers' risk exposures during M\&A announcements irrespective of whether the acquirer performs a cross-border or domestic M\&A.

Complexity of the transaction The complexity of an M\&A transaction may be another factor that influences the investor's perception of an acquiring firm's credit risk exposure and hence, the CAACSC. The complexity of the transaction increases with the deal size of the M\&A due to the more complicated integration process of large targets and higher uncertainty concerning the expected synergy effects (Alexandridis et al., 2013). There is strong empirical evidence that acquirers experience larger losses when taking over large targets (when performing more complex M\&A transactions) since

\footnotetext{
${ }^{12}$ Note that, the acquirers in our sample are not exposed to target country-specific risk factors since we investigate only complete M\&A transaction announcement. This is due to the fact, that (as compared to a partial M\&A) the target firm does not remain an entity under the jurisdiction of its head office's country (Bris and Cabolis, 2008; Ismailescu and Col, 2016).
} 
they are more likely to pay too much due to manager overconfidence or higher private benefits of CEOs (Loderer and Martin, 1990; Hayward and Hambrick, 1997; Grinstein and Hribar, 2004; Harford and Li, 2007; Malmendier and Tate, 2008; Alexandridis et al., 2013). Therefore, investors in CDS that are written on acquiring firms may perceive higher credit risk exposures due to a large complexity of the M\&A transaction. However, Alexandridis et al. (2013) empirically analyze acquirers during large deals and find that acquiring firms have a lower overpayment potential as compared to acquirers during small transactions. This might initially be due to the facts that there are less competitors in large deals that mitigate the 'winners curse' (Gorton et al., 2009). Furthermore, there is less concentrated managerial ownership resulting in insiders that accept smaller premia (Demsetz and Lehn, 1985; Bauguess et al., 2009). And finally, acquirers expecting a higher complexity hesitate to offer high premiums (Alexandridis et al., 2013), which may lead to a lower risk perception by CDS investor and hence, to a lower CAACSCs.

We employ three proxies to measure the degree of complexity in M\&A transactions, i.e. (i) the absolute US dollar amount paid by the acquirer (transaction volume), (ii) the relative amount paid to the size of the acquirer (transaction volume ratio) and (iii) the relative size of the target to the size of the acquirer (size ratio). As reported by Panel D in Table 14, the CAACSC increases significantly after the announcement of an abovemedian-size deal in our sample, while no significant effect is found for below-median-size deals for the subgroups (i) and (ii). In addition, as regards subgroup (iii), we find that the CAACSC increases for both, the above and below median subsample. The difference in means of about 577 bps and 541 bps is significant at the 1\%-level for subgroups (i) and (ii) while the difference of 209 bps for (iii) is smaller but still significant at the 10\%-level. Hence, our results suggest that CDS investors perceive M\&A announcements of more complex deals as more risky as compared to simpler transactions, regardless of whether an absolute or relative complexity measure is used. 


\subsubsection{Firm characteristics}

In this section, we employ several acquiring and target firm characteristics and investigate, if and to what extent these characteristics may influence the risk perception of acquiring firms' CDS investors concerning during the M\&A announcements from our sample.

Size To begin with, we analyze if the CDS investor's risk perception depends on the acquiring or target firm's size, which is measured as the firm's total assets. A large acquirer (target) may realize, ceteris paribus, a stronger coinsurance effect, which benefits the target's (acquirer's) debtholders and, therefore, may decrease the probability of default of the combined entity (Lewellen, 1971; Billett et al., 2004). In addition, it is suggested that the integration of larger targets may be more complicated as compared to smaller counterparts (Alexandridis et al., 2013). Taking this into account, we expect that CDS investors perceive a higher risk for acquirers during M\&As with larger targets.

As shown by Panel A in Table 15, we find a significant difference for transactions conducted by small and large acquirers in our sample of about 236 bps which supports theoretical predictions provided by Lewellen (1971) and Billett et al. (2004). However, Panel A in Table 16 reveals that this relationship does not hold when investigating size differences of target firms. In sum, findings from respective Panels $\mathrm{A}$ in Tables 15 and 16 suggest that the CAACSCs significantly increase in all subsamples due to an M\&A announcement, but that the coinsurance effect may lead to a less pronounced risk perception of acquirers' CDS investors for above-median-size acquiring firms.

Leverage As argued by Shastri (1990) and Billett et al. (2004), M\&As between firms with different leverage ratios may result in a decrease in the leverage ratio of the highlevered firm and an increase in the leverage ratio of the less capitalized firm. If this is true, the probability of default should decrease for higher levered firms due to a decreasing leverage ratio after the $\mathrm{M} \& \mathrm{~A}$ transaction. In contrast, the probability of default of the lower levered firm is expected to increase due to a higher leverage ratio. Obviously, this theoretical channel assumes that no anticipated post-merger effects of leverage changes 
exist, which origin from the M\&A announcement itself (Billett et al., 2004). In contrast, Levy and Sarnat (1970) as well as Lewellen (1971) find that leverage ratios of the combined firm increase after a merger when acquirers strengthen debt-financing in order to realize the M\&A transaction.

We initially employ leverage ratios of the acquirers (Table 15, Panel B (i)) and target firms (Table 16, Panel B) during the year before the announcement in order to analyze if the CDS investor's risk perception depends on differences in leverage ratios from acquiring and target firms, respectively. Additionally, we split our sample into a subsample of acquirers that take over companies with higher and lower leverage ratios (Table 15, Panel B (ii)). Finally, we analyze whether an acquirer's change in leverage between the pre- and post-merger announcement may influence the CDS investor's risk perception (Table 15, Panel B (iii)).

Overall, we find a significant increase in CAACSCs independent from the respective subsample (Panels B in Tables 15 and 16). However, referring to the respective differences in means, we do not find a significant difference when splitting our sample in above and below median acquiring and target firms' leverage ratios (Panel B (i) in Table 15 and Panel B in Table 16). In contrast, and in line with the theoretical predictions by Shastri (1990) and Billett et al. (2004), we observe that acquiring firms, that purchase higher levered target firms, exhibit a significantly higher CAACSC. On average, these acquiring firms have a higher CAACSC of about 548 bps as compared to acquirers that buy target firms with a lower leverage ratio. Accordingly, the CDS investors of the acquiring firm perceive a higher risk exposure after the M\&A announcement if the target firm exhibits a higher leverage ratio as compared to the acquiring firm (Panel B (ii) in Table 15). Finally, Panel B (iii) in Table 15 reports that acquiring firms with an above-median leverage ratio change between the pre- and post-merger announcement exhibit an about 217 bps higher CAACSC as compared to firms with a leverage ratio change below the sample median. Hence, we suggest that CDS investors of acquiring firms may perceive $\mathrm{M} \& \mathrm{~A}$ announcements more risky if leverage ratios rise as a result of debt financed M\&A transaction. 
Valuation Turning to the valuation of a firm, empirical evidence demonstrates that overvalued acquirers tend to perform poorly after M\&A deals (Dong et al., 2006; Song, 2007). This might be due to the fact that an overvaluation increases managerial discretion, which may provoke bad acquisition decisions and, as a last consequence, a decrease in shareholder and debtholder value (Jensen, 2005; Moeller et al., 2005; Akbulut, 2013; Ismailescu and Col, 2016). As regards the target firms, it is suggested that an overvaluation of the target firm incentivizes bidders to overpay.

In order to analyze if CAACSCs change due to an overvaluation of the acquiring or target firm, we follow Moeller et al. (2005) as well as Dong et al. (2006) and employ the market-to-book value to measure a firm's valuation. A higher market-to-book value indicates a greater overvaluation of the respective firm.

Respective Panels $\mathrm{C}$ in Tables 15 and 16 report a significant increase of the CAACSCs throughout the subsamples. However, as we do not find a significant difference between above-median and below-median valued acquirers, our results do not support theoretical predictions and empirical findings arguing that investors in CDS on acquirers with a higher market-to-book ratio expect a higher credit risk exposure at the acquiring firm of an M\&A transaction. In contrast, we provide empirical evidence that buying a target firm with an above median market-to-book ratio leads to a significantly higher CAACSC of 379 bps as compared to target firms with a below median market-to-book ratio. Thus, acquiring firms are perceived more risky by CDS investors if they take over target firms with higher market-to-book values due to possible overpayment incentives of acquirers.

Risk In a next step, we analyze if different firm-risk levels may have an impact on the CAACSCs. Thus, we initially split our sample into subsamples of investment and speculative grade rated acquirers and target firms. ${ }^{13}$ Furthermore, we split the sample by the average CDS spread of an acquirer within the $[-120,-21]$ window before the M\&A announcement since firms with a higher CDS spread should be more risky. This is due to

\footnotetext{
${ }^{13}$ We are aware of the fact that whether an acquirer has taken over a target firm with a lower or higher rating than its own would be a better proxy. Unfortunately, the number of observations is insufficient to build a respective subsample since most acquirers in our sample have a higher rating than the targets (see Table 9).
} 
the fact that protection sellers in the CDS market request a higher premium for default insurance. Since the number of observations of rated target firms is comparatively small (see Table 9), we additionally control if CAACSCs are different when a target firm is rated by at least one of the three biggest rating agencies (Moody's, Standard and Poor's or Fitch) or not. Theoretical models suggest that if the acquiring and target firm exhibit differences in asset-risk levels, or have imperfectly correlated unlevered asset returns, the asset risk of the high-risk firm should decrease while the asset value should increase. In contrast, the asset risk of the low-risk firm should increase while the asset value should decrease (Shastri, 1990; Billett et al., 2004).

As Panel D (i) in Table 15 reports, we find a significant increase in CAACSCs for acquirers exhibiting an investment grade rating which is in line with the theoretical predictions. In contrast, we do not find a significant effect for speculative grade rated acquirers. Similarly, we do not provide empirical evidence that the difference of CAACSCs of acquiring firms with an investment grade and a speculative rating is significant. Turning to the mean CDS level during the $[-120,-21]$ window before the M\&A announcement, we find that the CAACSCs for acquiring firms with low (high) pre-announcement CDS spreads increases by 401 bps (219 bps). Our results suggest that acquirers with low pre-announcement CDS spreads exhibit a stronger increase in CAACSCs around the announcement day (Panel D (ii) in Table 15). This difference of 182 bps is significant at the $10 \%$ level. Since acquiring firms with a low pre-announcement CDS spread are expected to be less risky, CDS investors perceive a stronger increase in the risk exposure at low-risk acquirers as compared to CDS investors of more risky acquirers (higher CDS spread). This finding is in line with theoretical predictions and empirical findings provided by Shastri (1990) and Billett et al. (2004).

Turning to target firms, Panel D (i) in Table 16 points to a significant increase of the CAACSC by 804 bps if acquirers take over speculative grade target firms, and by 572 bps if they take over investment grade target firms. Again, we do not find any significance in the difference between the rating classifications which might be due to the small number of observations. Moreover, splitting our sample in rated and unrated target firms in 
Panel D (ii) in Table 16, we find that M\&A announcements including both, unrated and rated targets result in CDS investors perceiving acquiring firms more risky. However, the positive impact on the acquirer's CAACSC is remarkably higher at 492 bps in case of M\&As including rated target firms. This could be due to the fact, that the transactions of rated firms are more complex. Accordingly, we observe a transaction volume of rated firms that is more than 3.3 times higher as compared to those with unrated firms. In addition, rated targets exhibit a 1.8 times higher leverage ratio while acquirers buying rated firms show a 2.3 times higher market-to-book value as compared to non-rated targets in our sample. As argued above, these factors may be determinants of the statistically significant difference in CAACSCs between rated and unrated target firms.

Regulation Following Billett et al. (2004) and Song (2007), we control if the CDS investors' risk perceptions differ with regard to M\&A transactions within high-regulated sectors (financials, utilities and energy firms) as compared to all other unregulated sectors. From a theoretical point of view, acquirers in highly regulated sectors should exhibit less credit risk after an M\&A announcement. This can be explained by the fact that superordinated organizations (e.g. municipalities, governments or other regulators) are interested in a low probability of default since these firms from the highly regulated sector typically are relevant for the system and life (e.g. banks, insurances, energy providers or water suppliers). Thus, CDS investors in highly regulated sectors may anticipate governmental aid if an acquiring firm may get into financial distress as a result of a risky merger.

As seen in Panel E from Table 15, highly regulated sectors reveal a CAACSC of 246 bps which is significant at the 10\%-level, whereas unregulated sectors exhibit a remarkably higher CAACSC of 328 bps which is significant at the 1\%-level. However, the difference of the CAACSCs between high-regulated and unregulated sectors is not statistically significant.

Publicly listed Taking into account that there is less information on private target firms available than it is the case for publicly listed firms (Chang, 1998; Fuller et al., 
2002; Koeplin et al., 2000; Kooli et al., 2003), this lack of information may hamper the acquirer to properly value the target firm during the due diligence process (Capron and Shen, 2007). In contrast, however, less information on private targets may create more value-creating opportunities for exploiting private information as compared to public targets where the market of corporate control serves as an information-processing and asset valuation mechanism for all potential bidders (Capron and Shen, 2007).

Against this background, we control if M\&A announcements of private or publicly listed target firms may have a different impact on the CDS investors' risk perception and hence, the CAACSC. As reported by Panel E in Table 16, we find a higher and significant CAACSC when the target firm is a publicly listed firm, however, the difference between the CAACSCs is not significant.

\section{Summary and conclusion}

The paper at hand employs a sample of 492 announcements of complete M\&A transactions from North America and Europe. We empirically analyze if these announcements may have an impact on the risk perception of investors in CDS that are written on the acquiring firms by using the event study methodology. As related research papers provide mixed results concerning the impact of a complete takeover on the risk perception of investors, we extend the existing literature by analyzing the (cumulated) average abnormal CDS spread changes ((C)AACSCs) during a [-2,2] event window around the announcement day since the majority of previous research papers has primarily focused on bond prices and the distance to default. We employ CDS since they feature a high liquidity, are a directly observable, market-based measure and exhibit a high standardization. Moreover, we extend previous event studies that utilize CDS spreads by utilizing a four-factor model with different input parameters depending on the entities rating, the latest non-parametric test statistics and a $\operatorname{GARCH}(1,1)$ model.

The analysis initially reveals an economically and statistically significant increase in CAACSCs of about 310 bps during the analyzed [-2,2] event window due to M\&A announcements. In addition, we do not observe that investors in the CDS market 
anticipate the M\&A announcements although the CDS market is frequently used by insiders. Rather, we provide evidence that the information is processed two further days after the event date. During further analyses, we identify different deal and firm characteristics that have an impact on the acquirer CDS investors' risk-perceptions during an M\&A announcement. We find that CDS investors perceive an M\&A deal as more risky when the complexity of the transaction is high. Likewise, the CAACSCs are higher when acquirers purchase target firms with a higher leverage and a high market-to-book value. In addition, we observe a stronger increase in CAACSCs for CDS that are written on larger acquirers. Furthermore acquiring firms that exhibit a high mean CDS spread before the announcement, i.e. these firms are more risky, have a less pronounced increase in CAACSCs as compared to firms with a lower mean CDS spread. In contrast, M\&A transactions of acquirers that take over rated targets in our sample are perceived as more risky by CDS investors as compared to unrated target firms. Additionally, if acquiring firms perform mergers rather than acquisitions of assets, CDS investors perceive the transaction as more risky and therefore, an increase in CAACSCs is observed.

We empirically show that CDS investors perceive an increase in the risk exposure of the acquiring firms due to an M\&A announcement. Accordingly, this finding complements results from related studies that reveal a negative perception by bondholders of the acquiring firm. Our results suggest that CDS investors may stronger weigh detrimental effects of an M\&A deal, such as value destruction and a possible transfer of additional risk from the target to the acquirer. In contrast, benefits, like stronger diversification opportunities and efficiency gains, are less appraised. Accordingly, managers of acquiring firms should be aware of the fact that CDS investors (e.g., banks, insurance companies or funds) may value the risk of an M\&A transaction, which in turn will increase CDS spreads and will provoke higher future funding costs for the conglomerate. 


\section{References}

Acharya, V. V. and Johnson, T. C. (2007). Insider trading in credit derivatives. Journal of Financial Economics, 84(1):110-141.

Agrawal, A., Jaffe, J. F., and Mandelker, G. N. (1992). The post-merger performance of acquiring firms: A re-examination of an anomaly. The Journal of Finance, 47(4):1605-1621.

Akbulut, M. E. (2013). Do overvaluation-driven stock acquisitions really benefit acquirer shareholders? Journal of Financial and Quantitative Analysis, 48(4):1025-1055.

Alexandridis, G., Fuller, K. P., Terhaar, L., and Travlos, N. G. (2013). Deal size, acquisition premia and shareholder gains. Journal of Corporate Finance, 20:1-13.

Amihud, Y. and Lev, B. (1981). Risk reduction as a managerial motive for conglomerate mergers. The Bell Journal of Economics, 12(2):605-617.

Andres, C., Betzer, A., and Doumet, M. (2016). Measuring abnormal credit default swap spreads. Available at SSRN 2194320.

Aron, D. J. (1988). Ability, moral hazard, firm size, and diversification. The Rand Journal of Economics, 19(1):72-87.

Asquith, P. (1983). Merger bids, uncertainty, and stockholder returns. Journal of Financial Economics, 11(1-4):51-83.

Augustin, P., Subrahmanyam, M. G., Tang, D. Y., and Wang, S. Q. (2016). Credit default swaps: Past, present, and future. Annual Review of Financial Economics, 8:175-196.

Avinadav, T., Chernonog, T., and Perlman, Y. (2017). Mergers and acquisitions between risk-averse parties. European Journal of Operational Research, 259(3):926-934.

Bauguess, S. W., Moeller, S. B., Schlingemann, F. P., and Zutter, C. J. (2009). Ownership structure and target returns. Journal of Corporate Finance, 15(1):48-65. 
Bessembinder, H., Kahle, K. M., Maxwell, W. F., and Xu, D. (2008). Measuring abnormal bond performance. The Review of Financial Studies, 22(10):4219-4258.

Billett, M. T., King, T.-H. D., and Mauer, D. C. (2004). Bondholder wealth effects in mergers and acquisitions: New evidence from the 1980s and 1990s. The Journal of Finance, 59(1):107-135.

Boehmer, E., Masumeci, J., and Poulsen, A. B. (1991). Event-study methodology under conditions of event-induced variance. Journal of Financial Economics, 30(2):253-272.

Bradley, M., Desai, A., and Kim, E. H. (1988). Synergistic gains from corporate acquisitions and their division between the stockholders of target and acquiring firms. Journal of Financial Economics, 21(1):3-40.

Bris, A. and Cabolis, C. (2008). The value of investor protection: Firm evidence from cross-border mergers. The Review of Financial Studies, 21(2):605-648.

Brown, S. J. and Warner, J. B. (1985). Using daily stock returns: The case of event studies. Journal of Financial Economics, 14(1):3-31.

Bruner, R. F. (2002). Does M\&A pay? A survey of evidence for the decision-maker. Journal of Applied Finance, 12(1):48-68.

Campbell, J. Y., Lo, A. W.-C., and MacKinlay, A. C. (1997). The Econometrics of Financial Markets. Princeton University Press, Princeton, NJ.

Capron, L. and Shen, J.-C. (2007). Acquisitions of private vs. public firms: Private information, target selection, and acquirer returns. Strategic Management Journal, 28(9):891-911.

Cathcart, L., El-Jahel, L., and Evans, L. (2013). The correlation structure of the CDS market: An empirical investigation. The Journal of Fixed Income, 22(4):53-74.

Chang, S. (1998). Takeovers of privately held targets, methods of payment, and bidder returns. The Journal of Finance, 53(2):773-784. 
Christensen, C. M., Alton, R., Rising, C., and Waldeck, A. (2011). The new M\&A playbook. Harvard Business Review, 89(3):48-57.

Corrado, C. J. (1989). A nonparametric test for abnormal security-price performance in event studies. Journal of Financial Economics, 23(2):385 - 395.

Corrado, C. J. and Zivney, T. L. (1992). The specification and power of the sign test in event study hypothesis tests using daily stock returns. Journal of Financial and Quantitative Analysis, 27(3):465-478.

da Silva, P. P., Vieira, I., and Vieira, C. (2015). M\&A operations: Further evidence of informed trading in the CDS market. Journal of Multinational Financial Management, 32-33:116-130.

Demsetz, H. and Lehn, K. (1985). The structure of corporate ownership: Causes and consequences. Journal of Political Economy, 93(6):1155-1177.

Dennis, D. K. and McConnell, J. J. (1986). Corporate mergers and security returns. Journal of Financial Economics, 16(2):143-187.

Dodd, P. (1980). Merger proposals, management discretion and stockholder wealth. Journal of Financial Economics, 8(2):105-137.

Dodd, P. and Ruback, R. (1977). Tender offers and stockholder returns: An empirical analysis. Journal of Financial Economics, 5(3):351-373.

Dong, M., Hirshleifer, D., Richardson, S., and Teoh, S. H. (2006). Does investor misvaluation drive the takeover market? The Journal of Finance, 61(2):725-762.

Doukas, J. and Travlos, N. G. (1988). The effect of corporate multinationalism on shareholders' wealth: Evidence from international acquisitions. The Journal of Finance, 43(5):1161-1175.

Erel, I., Liao, R. C., and Weisbach, M. S. (2012). Determinants of cross-border mergers and acquisitions. The Journal of Finance, 67(3):1045-1082. 
Fama, E. F. (1970). Efficient capital markets: A review of theory and empirical work. The Journal of Finance, 25(2):383-417.

Farruggio, C., Michalak, T. C., and Uhde, A. (2013). The light and dark side of tarp. Journal of Banking 65 Finance, 37(7):2586-2604.

Francis, B. B., Hasan, I., and Sun, X. (2008). Financial market integration and the value of global diversification: Evidence for us acquirers in cross-border mergers and acquisitions. Journal of Banking \& Finance, 32(8):1522-1540.

Franks, J. R. and Harris, R. S. (1989). Shareholder wealth effects of corporate takeovers: The UK experience 1955-1985. Journal of Financial Economics, 23(2):225-249.

Fuller, K., Netter, J., and Stegemoller, M. (2002). What do returns to acquiring firms tell us? Evidence from firms that make many acquisitions. The Journal of Finance, 57(4):1763-1793.

Furfine, C. H. and Rosen, R. J. (2011). Mergers increase default risk. Journal of Corporate Finance, 17(4):832-849.

Goergen, M. and Renneboog, L. (2004). Shareholder wealth effects of european domestic and cross-border takeover bids. European Financial Management, 10(1):9-45.

Gorton, G., Kahl, M., and Rosen, R. J. (2009). Eat or be eaten: A theory of mergers and firm size. The Journal of Finance, 64(3):1291-1344.

Greatrex, C. A. (2009). Credit default swap market determinants. The Journal of Fixed Income, 18(3):18.

Grinstein, Y. and Hribar, P. (2004). CEO compensation and incentives: Evidence from M\&A bonuses. Journal of Financial Economics, 73(1):119-143.

Hann, R. N., Ogneva, M., and Ozbas, O. (2013). Corporate diversification and the cost of capital. The Journal of Finance, 68(5):1961-1999. 
Harford, J., Humphery-Jenner, M., and Powell, R. (2012). The sources of value destruction in acquisitions by entrenched managers. Journal of Financial Economics, 106(2):247261.

Harford, J. and Li, K. (2007). Decoupling CEO wealth and firm performance: The case of acquiring CEOs. The Journal of Finance, 62(2):917-949.

Harris, M., Kriebel, C. H., and Raviv, A. (1982). Asymmetric information, incentives and intrafirm resource allocation. Management Science, 28(6):604-620.

Hayward, M. L. A. and Hambrick, D. C. (1997). Explaining the premiums paid for large acquisitions: Evidence of CEO hubris. Administrative science quarterly, pages $103-127$.

Higgins, R. C. and Schall, L. D. (1975). Corporate bankruptcy and conglomerate merger. The Journal of Finance, 30(1):93-113.

Hraschek, M., Mietzner, M., and Tyrell, M. (2016). A note on credit derivatives and M\&A transactions: Announcement and anticipation effects. Corporate Ownership \& Control, 13(2):272-279.

Hüttermann, K. and Lleshaj, D. (2018). Debtholder wealth effects in mergers and acquisitions: Evidence from the CDS market. Working Paper.

Ismailescu, I. and Col, B. (2016). Cross-border M\&As and credit risk: Evidence from the CDS market. Available at SSRN 2779370.

Jansen, J. and Fabozzi, F. J. (2017). CDS implied credit ratings. The Journal of Fixed Income, 26(4):25-52.

Jensen, M. C. (1986). Agency costs of free cash flow, corporate finance, and takeovers. The American Economic Review, 76(2):323-329.

Jensen, M. C. (2005). Agency costs of overvalued equity. Financial Management, 34(1):519. 
Jensen, M. C. and Ruback, R. S. (1983). The market for corporate control: The scientific evidence. Journal of Financial Economics, 11(1-4):5-50.

Jorion, P., Liu, Z., and Shi, C. (2005). Informational effects of regulation FD: Evidence from rating agencies. Journal of Financial Economics, 76(2):309-330.

Kim, E. H. and McConnell, J. J. (1977). Corporate mergers and the co-insurance of corporate debt. The Journal of Finance, 32(2):349-365.

Koeplin, J., Sarin, A., and Shapiro, A. C. (2000). The private company discount. Journal of Applied Corporate Finance, 12(4):94-101.

Kolari, J. W. and Pynnonen, S. (2011). Nonparametric rank tests for event studies. Journal of Empirical Finance, 18(5):953-971.

Kooli, M., Kortas, M., and L'her, J.-F. (2003). A new examination of the private company discount: The acquisition approach. The Journal of Private Equity, 6(3):48-55.

Kuppuswamy, V. and Villalonga, B. (2015). Does diversification create value in the presence of external financing constraints? Evidence from the 2007-2009 financial crisis. Management Science, 62(4):905-923.

Laeven, L. and Levine, R. (2007). Is there a diversification discount in financial conglomerates? Journal of Financial Economics, 85(2):331-367.

Leland, H. E. (2007). Financial synergies and the optimal scope of the firm: Implications for mergers, spinoffs, and structured finance. The Journal of Finance, 62(2):765-807.

Levy, H. and Sarnat, M. (1970). Diversification, portfolio analysis and the uneasy case for conglomerate mergers. The Journal of Finance, 25(4):795-802.

Lewellen, W. G. (1971). A pure financial rationale for the conglomerate merger. The Journal of Finance, 26(2):521-537.

Loderer, C. and Martin, K. (1990). Corporate acquisitions by listed firms: The experience of a comprehensive sample. Financial management, pages 17-33. 
Longstaff, F. A., Pan, J., Pedersen, L. H., and Singleton, K. J. (2011). How sovereign is sovereign credit risk? American Economic Journal: Macroeconomics, 3(2):75-103.

MacKinlay, A. C. (1997). Event studies in economics and finance. Journal of Economic Literature, 35(1):13-39.

Malatesta, P. H. (1983). The wealth effect of merger activity and the objective functions of merging firms. Journal of Financial Economics, 11(1-4):155-181.

Malmendier, U. and Tate, G. (2008). Who makes acquisitions? CEO overconfidence and the market's reaction. Journal of Financial Economics, 89(1):20-43.

Masulis, R. W., Wang, C., and Xie, F. (2007). Corporate governance and acquirer returns. The Journal of Finance, 62(4):1851-1889.

Meyer, M., Milgrom, P., and Roberts, J. (1992). Organizational prospects, influence costs, and ownership changes. Journal of Economics \& Management Strategy, 1(1):9-35.

Moeller, S. B., Schlingemann, F. P., and Stulz, R. M. (2005). Wealth destruction on a massive scale? A study of acquiring-firm returns in the recent merger wave. The Journal of Finance, 60(2):757-782.

Myerson, R. B. (1982). Optimal coordination mechanisms in generalized principal-agent problems. Journal of Mathematical Economics, 10(1):67-81.

Oehmke, M. and Zawadowski, A. (2016). The anatomy of the CDS market. The Review of Financial Studies, 30(1):80-119.

Patell, J. M. (1976). Corporate forecasts of earnings per share and stock price behavior: Empirical test. Journal of Accounting Research, 14(2):246-276.

Rau, P. R. and Vermaelen, T. (1998). Glamour, value and the post-acquisition performance of acquiring firms. Journal of Financial Economics, 49(2):223-253.

Rose, A. K., Lockwood, B., and Quah, D. (2000). One money, one market: Estimating the effect of common currencies on trade. Economic Policy, 15(30):7-45. 
Rotemberg, J. J. and Saloner, G. (1994). Benefits of narrow business strategies. The American Economic Review, 84(5):1330-1349.

Shastri, K. (1990). The differential effects of mergers on corporate security values. Research in Finance, 8:179-201.

Shrivastava, P. (1986). Postmerger integration. Journal of Business Strategy, 7(1):65-76.

Song, W. (2007). Does overvaluation lead to bad mergers? In AFA 2007 Chicago Meetings Paper.

Stulz, R. M. (1990). Managerial discretion and optimal financing policies. Journal of Financial Economics, 26(1):3-27.

Vallascas, F. and Hagendorff, J. (2011). The impact of european bank mergers on bidder default risk. Journal of Banking \& Finance, 35(4):902-915.

Wilcoxon, F. (1945). Individual comparisons by ranking methods. Biometrics Bulletin, $1(6): 80-83$. 


\section{Empirical Appendix}

Figure 1: Development of M\&A activity in North America and Europe from 1985 to 2018

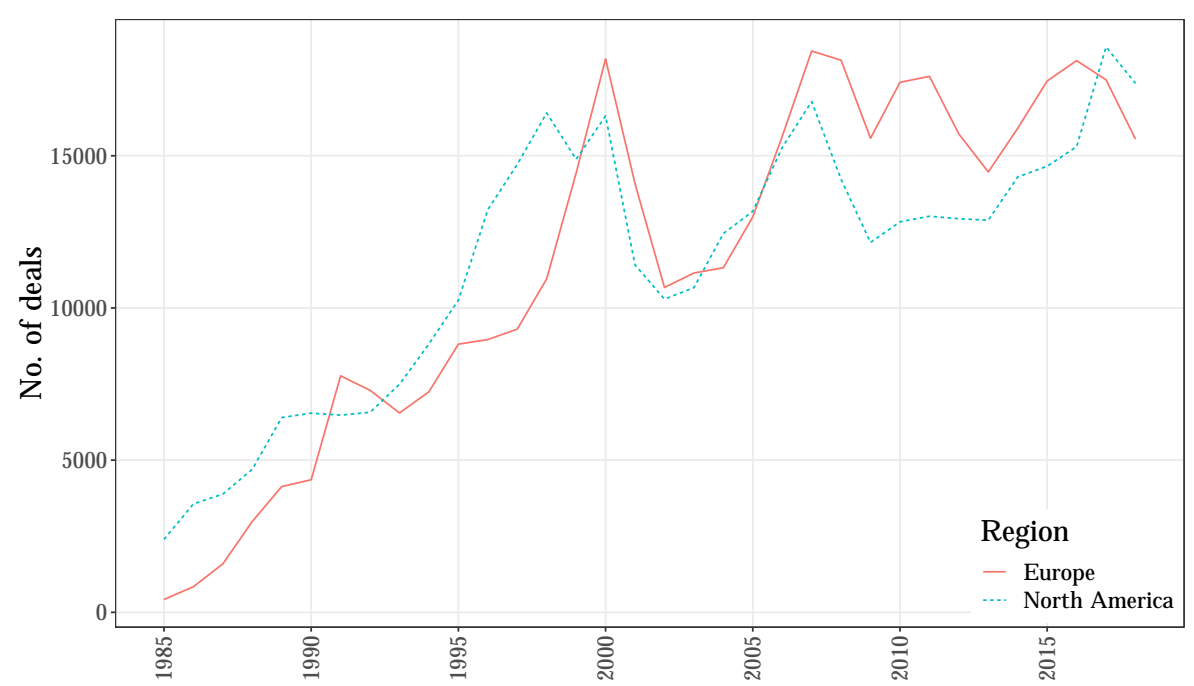

(a) This subfigure shows the number of all M\&A transactions in North America (red) and Europe (blue) from 1985 to 2018. The data is retrieved from the Institute for Mergers, Acquisitions and Alliances (IMAA).

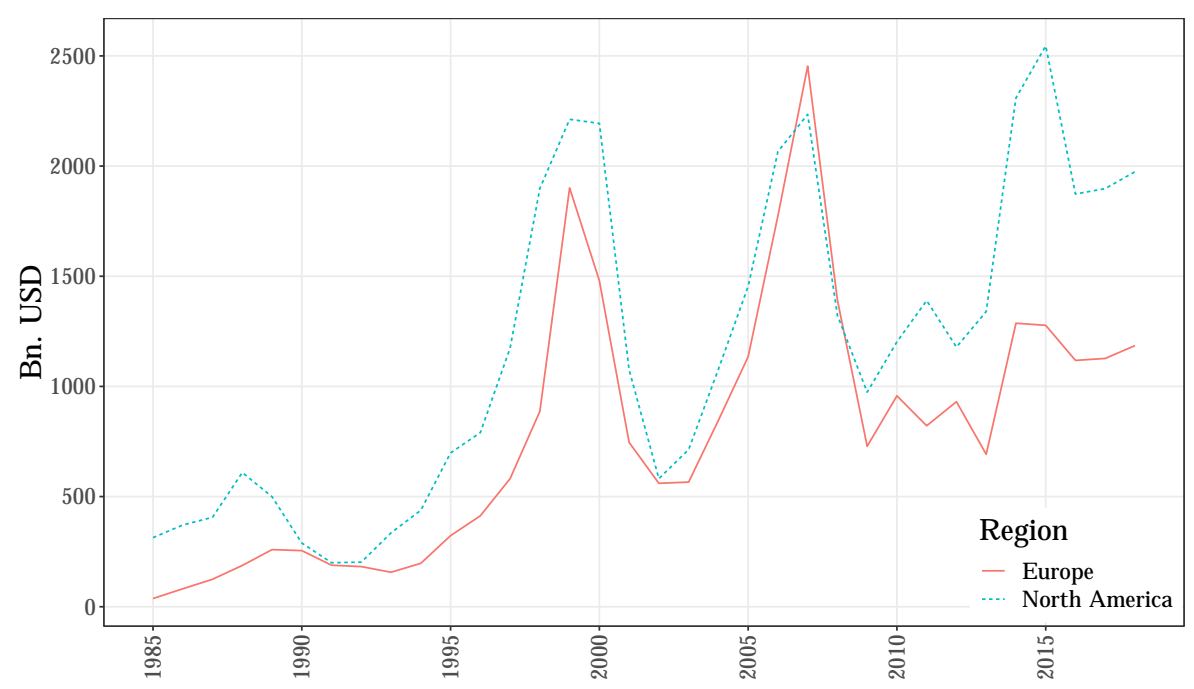

(b) This subfigure shows the value in billions of US dollars of all M\&A transactions in North America (red) and Europe (blue) from 1985 to 2018. The data is retrieved from the Institute for Mergers, Acquisitions and Alliances (IMAA). 
Table 1: Number of M\&A announcements by year and acquirers' region

\begin{tabular}{rrrr}
\hline \hline Year & Europe & North America & Total \\
\hline 2005 & 17 & 18 & 35 \\
2006 & 28 & 27 & 55 \\
2007 & 21 & 32 & 53 \\
2008 & 11 & 14 & 25 \\
2009 & 6 & 25 & 31 \\
2010 & 10 & 29 & 39 \\
2011 & 11 & 28 & 39 \\
2012 & 13 & 26 & 39 \\
2013 & 10 & 17 & 27 \\
2014 & 11 & 23 & 34 \\
2015 & 13 & 32 & 45 \\
2016 & 15 & 23 & 38 \\
2017 & 5 & 15 & 20 \\
2018 & 2 & 10 & 12 \\
\hline Total & 173 & 319 & 492 \\
\hline \hline
\end{tabular}


Table 2: Number of M\&A announcements according to the acquirers' countries

\begin{tabular}{lr}
\hline \hline Country & No. of M\&As \\
\hline Belgium & 2 \\
Canada & 1 \\
Denmark & 1 \\
Finland & 8 \\
France & 30 \\
Germany & 22 \\
Iceland & 1 \\
Italy & 9 \\
Luxembourg & 1 \\
Netherlands & 17 \\
Norway & 5 \\
Poland & 1 \\
Puerto Rico & 1 \\
Spain & 13 \\
Sweden & 21 \\
Switzerland & 12 \\
United Kingdom & 30 \\
United States & 317 \\
\hline Total & 492 \\
\hline \hline
\end{tabular}


Table 3: Number of M\&A announcements according to the acquirers' Markit sector classifications and regions

\begin{tabular}{lrrr}
\hline \hline Sector & Europe & North America & Total \\
\hline Basic Materials & 15 & 25 & 40 \\
Consumer Goods & 24 & 33 & 57 \\
Consumer Services & 20 & 34 & 54 \\
Energy & 6 & 32 & 38 \\
Financials & 23 & 27 & 50 \\
Healthcare & 14 & 45 & 59 \\
Industrials & 34 & 51 & 85 \\
Technology & 14 & 49 & 63 \\
Telecommunications Services & 14 & 11 & 25 \\
Utilities & 9 & 12 & 21 \\
\hline Total & 173 & 319 & 492 \\
\hline \hline
\end{tabular}


Table 4: Number of M\&A announcements according to acquirers' Markit sector classification and year

\begin{tabular}{lrrrrrrrrrrrrrrr}
\hline \hline Sector & 2005 & 2006 & 2007 & 2008 & 2009 & 2010 & 2011 & 2012 & 2013 & 2014 & 2015 & 2016 & 2017 & 2018 & Total \\
\hline Basic Materials & 1 & 5 & 6 & 2 & 0 & 3 & 6 & 5 & 1 & 3 & 5 & 3 & 0 & 0 & 40 \\
Consumer Goods & 3 & 4 & 5 & 2 & 6 & 5 & 2 & 4 & 0 & 4 & 7 & 6 & 6 & 3 & 57 \\
Consumer Services & 1 & 4 & 6 & 3 & 1 & 3 & 7 & 2 & 7 & 5 & 8 & 3 & 2 & 2 & 54 \\
Energy & 2 & 3 & 2 & 0 & 4 & 5 & 3 & 3 & 2 & 1 & 4 & 3 & 4 & 2 & 38 \\
Financials & 5 & 12 & 6 & 2 & 3 & 0 & 5 & 5 & 1 & 6 & 2 & 0 & 2 & 1 & 50 \\
Healthcare & 4 & 4 & 5 & 6 & 3 & 7 & 2 & 9 & 2 & 6 & 4 & 5 & 1 & 1 & 59 \\
Industrials & 6 & 7 & 7 & 4 & 3 & 9 & 10 & 8 & 9 & 3 & 6 & 9 & 1 & 3 & 85 \\
Technology & 7 & 9 & 11 & 4 & 7 & 4 & 1 & 3 & 1 & 2 & 7 & 5 & 2 & 0 & 63 \\
Telecommunications Services & 6 & 2 & 3 & 1 & 4 & 0 & 2 & 0 & 1 & 2 & 0 & 2 & 2 & 0 & 25 \\
Utilities & 0 & 5 & 2 & 1 & 0 & 3 & 1 & 0 & 3 & 2 & 2 & 2 & 0 & 0 & 21 \\
\hline Total & 35 & 55 & 53 & 25 & 31 & 39 & 39 & 39 & 27 & 34 & 45 & 38 & 20 & 12 & 492 \\
\hline \hline
\end{tabular}


Table 5: Number of M\&A announcements according to target firms' home countries and acquirer firms' regions

\begin{tabular}{|c|c|c|c|}
\hline Target country & Europe & North America & Total \\
\hline Australia & 3 & 6 & 9 \\
\hline Belgium & 3 & 2 & 5 \\
\hline Bermuda & 1 & 2 & 3 \\
\hline Brazil & 2 & 2 & 4 \\
\hline Canada & 8 & 13 & 21 \\
\hline China & 3 & 1 & 4 \\
\hline Denmark & 7 & 3 & 10 \\
\hline Egypt & 1 & 0 & 1 \\
\hline Finland & 1 & 0 & 1 \\
\hline France & 11 & 2 & 13 \\
\hline Germany & 7 & 5 & 12 \\
\hline Guernsey & 1 & 0 & 1 \\
\hline Ireland & 0 & 3 & 3 \\
\hline Isle of Man & 0 & 1 & 1 \\
\hline Israel & 0 & 2 & 2 \\
\hline Italy & 6 & 4 & 10 \\
\hline Luxembourg & 0 & 1 & 1 \\
\hline Netherlands & 5 & 1 & 6 \\
\hline Norway & 7 & 1 & 8 \\
\hline Poland & 1 & 0 & 1 \\
\hline Puerto Rico & 0 & 1 & 1 \\
\hline Singapore & 1 & 1 & 2 \\
\hline South Africa & 1 & 0 & 1 \\
\hline Spain & 11 & 3 & 14 \\
\hline Sweden & 5 & 3 & 8 \\
\hline United Kingdom & 26 & 17 & 43 \\
\hline United States & 62 & 245 & 307 \\
\hline Total & 173 & 319 & 492 \\
\hline
\end{tabular}


Table 6: Number of M\&A announcements according to targets' Markit sector classification and acquirers' region

\begin{tabular}{lrrr}
\hline \hline Sector & Europe & North America & Total \\
\hline Basic Materials & 14 & 25 & 39 \\
Consumer Goods & 16 & 40 & 56 \\
Consumer Services & 21 & 26 & 47 \\
Energy & 6 & 36 & 42 \\
Financials & 26 & 22 & 48 \\
Healthcare & 16 & 54 & 70 \\
Industrials & 30 & 33 & 63 \\
Technology & 20 & 59 & 79 \\
Telecommunications Services & 14 & 15 & 29 \\
Utilities & 10 & 9 & 19 \\
\hline Total & 173 & 319 & 492 \\
\hline \hline
\end{tabular}


Table 7: Number of M\&A according to targets' Markit sector classification and year

\begin{tabular}{|c|c|c|c|c|c|c|c|c|c|c|c|c|c|c|c|}
\hline Sector & 2005 & 2006 & 2007 & 2008 & 2009 & 2010 & 2011 & 2012 & 2013 & 2014 & 2015 & 2016 & 2017 & 2018 & Total \\
\hline Basic Materials & 0 & 5 & 6 & 2 & 0 & 3 & 6 & 1 & 1 & 4 & 6 & 5 & 0 & 0 & 39 \\
\hline Consumer Goods & 5 & 2 & 4 & 3 & 6 & 4 & 3 & 5 & 3 & 2 & 8 & 6 & 2 & 3 & 56 \\
\hline Consumer Services & 1 & 1 & 3 & 1 & 3 & 3 & 6 & 5 & 6 & 4 & 5 & 4 & 3 & 2 & 47 \\
\hline Energy & 4 & 4 & 3 & 0 & 3 & 5 & 3 & 3 & 2 & 2 & 4 & 3 & 4 & 2 & 42 \\
\hline Financials & 6 & 12 & 6 & 3 & 2 & 0 & 2 & 4 & 1 & 6 & 3 & 0 & 2 & 1 & 48 \\
\hline Healthcare & 4 & 7 & 6 & 6 & 2 & 7 & 4 & 13 & 2 & 6 & 4 & 6 & 2 & 1 & 70 \\
\hline Industrials & 3 & 8 & 8 & 3 & 2 & 7 & 8 & 4 & 4 & 2 & 3 & 6 & 3 & 2 & 63 \\
\hline Technology & 6 & 9 & 12 & 5 & 8 & 7 & 4 & 4 & 2 & 6 & 8 & 5 & 2 & 1 & 79 \\
\hline Telecommunications Services & 6 & 3 & 4 & 1 & 4 & 0 & 2 & 0 & 2 & 2 & 1 & 2 & 2 & 0 & 29 \\
\hline Utilities & 0 & 4 & 1 & 1 & 1 & 3 & 1 & 0 & 4 & 0 & 3 & 1 & 0 & 0 & 19 \\
\hline Total & 35 & 55 & 53 & 25 & 31 & 39 & 39 & 39 & 27 & 34 & 45 & 38 & 20 & 12 & 492 \\
\hline
\end{tabular}


Table 8: Notes on variables and data sources

\begin{tabular}{|c|c|c|c|}
\hline Variable & Proxy & Description & Source \\
\hline \multicolumn{4}{|l|}{ Deal characteristics } \\
\hline Diversification & $\begin{array}{l}\text { Diversified M\&A } \\
\text { transaction }\end{array}$ & $\begin{array}{l}\text { Dummy variable that takes on the value of } 1 \text { if the } \\
\text { Markit sector classification of a target is different to } \\
\text { the acquirer. }\end{array}$ & Markit, own calc. \\
\hline Merger & Type of transaction & $\begin{array}{l}\text { Dummy variable that indicates whether the } \\
\text { transaction type is a merger or not. }\end{array}$ & $\begin{array}{l}\text { Thomson Reuter's } \\
\text { SDC Platinum }\end{array}$ \\
\hline Cross-border & $\begin{array}{l}\text { Cross-border M\&A } \\
\text { transaction }\end{array}$ & $\begin{array}{l}\text { Dummy variable that takes on the value of } 1 \text { if the } \\
\text { transaction is performed cross-border and } 0 \text { otherwise. }\end{array}$ & \\
\hline Transaction volume & $\begin{array}{l}\text { Complexity of the } \\
\text { M\&A transaction }\end{array}$ & $\begin{array}{l}\text { US dollar amount paid by the acquirer for the takeover } \\
\text { in millions }\end{array}$ & \\
\hline $\begin{array}{l}\text { Transaction volume } \\
\text { ratio }\end{array}$ & & $\begin{array}{l}\text { Relative size of the transaction volume of the M\&A to } \\
\text { an acquirers book value of total assets in the year } \\
\text { before the transaction. }\end{array}$ & $\begin{array}{l}\text { Thomson Reuter's } \\
\text { SDC Platinum and } \\
\text { Worldscope, own calc. }\end{array}$ \\
\hline Size ratio & & $\begin{array}{l}\text { Pre-merger ratio of the book value of a target's total } \\
\text { assets to an acquirer's total assets. }\end{array}$ & $\begin{array}{l}\text { Thomson Reuter's } \\
\text { Worldscope, own calc. }\end{array}$ \\
\hline \multicolumn{4}{|c|}{ Acquirer and target characteristics } \\
\hline Total assets & Size & $\begin{array}{l}\text { Book value of total assets of an acquirer/a target in } \\
\text { millions of US dollars in the year before the } \\
\text { announcement. }\end{array}$ & $\begin{array}{l}\text { Thomson Reuter's } \\
\text { Worldscope }\end{array}$ \\
\hline
\end{tabular}


Table 8: Notes on variables and data sources (continued)

\begin{tabular}{|c|c|c|c|}
\hline Variable & Proxy & Description & Source \\
\hline Leverage ratio & \multirow[t]{4}{*}{ Leverage } & $\begin{array}{l}\text { Debt-to-equity ratio in percent of an acquirer/a target } \\
\text { in the year before the transaction announcement. }\end{array}$ & \multirow{4}{*}{$\begin{array}{l}\text { Thomson Reuter's } \\
\text { Worldscope, own calc. }\end{array}$} \\
\hline Lower leverage than & & Dummy variable that indicates whether an acquirer & \\
\hline target & & $\begin{array}{l}\text { has a lower leverage than the target in the year before } \\
\text { the transaction. }\end{array}$ & \\
\hline Leverage change & & $\begin{array}{l}\text { Percentage change of an acquirer's leverage ratio from } \\
\text { the year before the M\&A announcement to the } \\
\text { leverage in the year of the M\&A announcement. }\end{array}$ & \\
\hline Market-to-book value & Valuation & $\begin{array}{l}\text { Product of the market price at the year before the } \\
\text { announcement times common shares outstanding in } \\
\text { millions of US dollars. }\end{array}$ & $\begin{array}{l}\text { Thomson Reuter's } \\
\text { Worldscope }\end{array}$ \\
\hline Rating & Risk & $\begin{array}{l}\text { Average acquirer's/target's issuer rating of Moody's, } \\
\text { Standard and Poors and Fitch, while } 1 \text { represents the } \\
\text { best rating and } 23 \text { the worst (see Jorion et al., } 2005 \text { for } \\
\text { the classification of the ratings). }\end{array}$ & $\begin{array}{l}\text { Thomson Reuter's } \\
\text { EIKON }\end{array}$ \\
\hline Mean CDS spread & & $\begin{array}{l}\text { Mean CDS spread of an acquirer during the }[-120,-21] \\
\text { window before the announcement day in basis points. }\end{array}$ & Markit, own calc. \\
\hline Rated & & $\begin{array}{l}\text { Variable that indicates whether a target has received a } \\
\text { rating from Moody's, Standard and Poor's or Fitch or } \\
\text { not. }\end{array}$ & $\begin{array}{l}\text { Thomson Reuter's } \\
\text { EIKON }\end{array}$ \\
\hline Regulated acquirer & Regulation & $\begin{array}{l}\text { Binary variable that indicates whether an acquirer } \\
\text { operates in the financial, utility or energy sector. }\end{array}$ & Markit, own calc. \\
\hline
\end{tabular}


Table 8: Notes on variables and data sources (continued)

\begin{tabular}{llll}
\hline Variable & Proxy & Description & Source \\
\hline Listed & Publicly listed & Binary variable that indicates whether a target is a & Thomson Reuter's \\
& & listed company or not. & SDC Platinum \\
Region North & Region & Dummy variable that takes on the value of 1 if an & \\
America & acquirer is from the North American region and 0 if & \\
& & the acquirer is located in Europe. & \\
\hline \hline
\end{tabular}


Table 9: Summary statistics

\begin{tabular}{|c|c|c|c|c|c|}
\hline & Mean & $\mathrm{SD}$ & Min. & Max. & $\mathrm{N}$ \\
\hline \multicolumn{6}{|l|}{ Deal characteristics } \\
\hline Diversification & 0.2480 & 0.4323 & 0.0000 & 1.0000 & 492 \\
\hline Merger & 0.8394 & 0.3675 & 0.0000 & 1.0000 & 492 \\
\hline Cross-border & 0.4431 & 0.4973 & 0.0000 & 1.0000 & 492 \\
\hline Transaction volume (\$m) & $4,440.8227$ & $9,470.9234$ & 2.5000 & $101,475.7900$ & 492 \\
\hline Transaction volume ratio (\%) & 19.2973 & 33.8663 & 0.0055 & 231.0269 & 443 \\
\hline Size ratio $(\%)$ & 50.3159 & 275.7725 & 0.0061 & $4,243.6740$ & 290 \\
\hline \multicolumn{6}{|l|}{ Acquirer characteristics } \\
\hline Total assets $(\$ \mathrm{~m})$ & $63,595.2230$ & $170,064.1155$ & 957.3970 & $2,172,924.0000$ & 443 \\
\hline Leverage ratio (\%) & 135.5824 & 380.1629 & 1.6400 & 5001.9500 & 432 \\
\hline Lower leverage than target & 0.4083 & 0.4926 & 0.0000 & 1.0000 & 240 \\
\hline Leverage change (\%) & 29.3614 & 110.5616 & -96.6947 & $1,183.6045$ & 416 \\
\hline Market-to-book value (\%) & 4.6634 & 23.2262 & 0.4400 & 494.7700 & 474 \\
\hline Rating & 7.4309 & 2.8423 & 1.0000 & 18.0000 & 492 \\
\hline Mean CDS spread (bps) & 103.1256 & 158.6574 & 4.7150 & $2,106.2096$ & 492 \\
\hline Regulation & 0.1443 & 0.3518 & 0.0000 & 1.0000 & 492 \\
\hline Region North America & 0.6484 & 0.4780 & 0.0000 & 1.0000 & 492 \\
\hline \multicolumn{6}{|l|}{ Target characteristics } \\
\hline Total assets $(\$ \mathrm{~m})$ & $5,717.5334$ & $18,662.2264$ & 12.4180 & $272,109.0000$ & 326 \\
\hline Leverage ratio $(\%)$ & 134.4338 & 316.8574 & 0.0100 & $3,665.0500$ & 265 \\
\hline Market-to-book value (\%) & 3.9272 & 8.1003 & 0.2700 & 95.3300 & 328 \\
\hline Rating & 10.6500 & 2.9324 & 4.0000 & 17.0000 & 120 \\
\hline Rated & 0.2439 & 0.4299 & 0.0000 & 1.0000 & 492 \\
\hline Listed & 0.7967 & 0.4028 & 0.0000 & 1.0000 & 492 \\
\hline
\end{tabular}

This table shows the summary statistics of the 492 complete M\&A announcements of listed companies in North America and Europe between May 2005 and October 2018 from Thomson Reuter's SDC Platinum database. The variables are described in Table 8. 
Table 10: Summary statistics of North American and European M\&A announcements

\begin{tabular}{|c|c|c|c|c|c|c|c|c|c|c|}
\hline & \multicolumn{5}{|c|}{ North America } & \multicolumn{5}{|c|}{ Europe } \\
\hline & Mean & $\mathrm{SD}$ & Min. & Max. & $\mathrm{N}$ & Mean & $\mathrm{SD}$ & Min. & Max. & $\mathrm{N}$ \\
\hline \multicolumn{11}{|l|}{ Deal characteristics } \\
\hline Diversification & 0.2038 & 0.4034 & 0.0000 & 1.0000 & 319 & 0.3295 & 0.4714 & 0.0000 & 1.0000 & 173 \\
\hline Merger & 0.8433 & 0.3641 & 0.0000 & 1.0000 & 319 & 0.8324 & 0.3746 & 0.0000 & 1.0000 & 173 \\
\hline Cross-border & 0.2351 & 0.4247 & 0.0000 & 1.0000 & 319 & 0.8266 & 0.3797 & 0.0000 & 1.0000 & 173 \\
\hline Transaction volume $(\$ \mathrm{~m})$ & $3,929.1760$ & $7,008.8067$ & 2.5000 & $62,141.0560$ & 319 & $5,384.2637$ & $12,800.6143$ & 3.7120 & $10,1475.7900$ & 173 \\
\hline Transaction volume ratio (\%) & 21.7903 & 35.0405 & 0.0150 & 231.0269 & 291 & 14.5245 & 31.0520 & 0.0055 & 201.7823 & 152 \\
\hline Size ratio $(\%)$ & 66.5409 & 338.5417 & 0.0061 & $4,243.6740$ & 188 & 20.4111 & 63.3807 & 0.0195 & 511.3888 & 102 \\
\hline \multicolumn{11}{|l|}{ Acquirer characteristics } \\
\hline Total assets $(\$ \mathrm{~m})$ & $52,332.8965$ & $146,333.2494$ & 957.3970 & $1,913,902.0000$ & 291 & $85,156.6506$ & $206,932.3533$ & $1,568.4000$ & $2,172,924.0000$ & 152 \\
\hline Leverage ratio (\%) & 152.9968 & 455.8176 & 2.1500 & 5001.9500 & 281 & 103.1754 & 160.6333 & 1.6400 & 1046.2800 & 151 \\
\hline Lower leverage than target & 0.4667 & 0.5004 & 0.0000 & 1.0000 & 165 & 0.2800 & 0.4520 & 0.0000 & 1.0000 & 75 \\
\hline Leverage change (\%) & 31.8803 & 109.4173 & -96.6947 & $1,124.1860$ & 279 & 24.1629 & 112.6767 & -63.9628 & $1,183.6045$ & 138 \\
\hline Market-to-book value (\%) & 5.6999 & 28.8291 & 0.4500 & 494.7700 & 306 & 2.7754 & 2.1095 & 0.4400 & 14.8600 & 168 \\
\hline Rating & 7.8276 & 3.0661 & 1.0000 & 18.0000 & 319 & 6.6994 & 2.2025 & 1.0000 & 13.0000 & 173 \\
\hline Mean CDS spread (bps) & 118.9744 & 185.2586 & 7.7094 & $2,106.2096$ & 319 & 73.9014 & 84.1396 & 4.7150 & 648.4683 & 173 \\
\hline Regulation & 0.1223 & 0.3281 & 0.0000 & 1.0000 & 319 & 0.1850 & 0.3894 & 0.0000 & 1.0000 & 173 \\
\hline
\end{tabular}


Table 10: Summary statistics of North American and European M\&A announcements (continued)

\begin{tabular}{|c|c|c|c|c|c|c|c|c|c|c|}
\hline & \multicolumn{5}{|c|}{ North America } & \multicolumn{5}{|c|}{ Europe } \\
\hline & Mean & $\mathrm{SD}$ & Min. & Max. & $\mathrm{N}$ & Mean & $\mathrm{SD}$ & Min. & Max. & $\mathrm{N}$ \\
\hline \multicolumn{11}{|l|}{ Target characteristics } \\
\hline Total assets $(\$ \mathrm{~m})$ & $6,388.6539$ & $21,279.1882$ & 12.5370 & $272,109.0000$ & 208 & $4,534.5413$ & $12,810.7052$ & 12.4180 & $127,254.0000$ & 118 \\
\hline Leverage ratio (\%) & 134.3840 & 311.6816 & 0.0100 & $3,665.0500$ & 181 & 134.5410 & 329.6411 & 0.0200 & $2,216.0300$ & 84 \\
\hline Market-to-book value (\%) & 4.3024 & 9.4357 & 0.5900 & 95.3300 & 226 & 3.0960 & 3.6168 & 0.2700 & 31.6200 & 102 \\
\hline Rating & 11.0112 & 2.8782 & 4.0000 & 17.0000 & 89 & 9.6129 & 2.8830 & 5.0000 & 16.0000 & 31 \\
\hline Rated & 0.2790 & 0.4492 & 0.0000 & 1.0000 & 319 & 0.1792 & 0.3846 & 0.0000 & 1.0000 & 173 \\
\hline Listed & 0.8182 & 0.3863 & 0.0000 & 1.0000 & 319 & 0.7572 & 0.4300 & 0.0000 & 1.0000 & 173 \\
\hline
\end{tabular}

This table shows the summary statistics of the 492 M\&A announcements between May 2005 and October 2018 from Thomson Reuter's SDC Platinum database split by the two regions

North America (319 M\&A announcements) and Europe (173 M\&A announcements). The variables are described in Table 8. 
Table 11: Acquirers' (C)AACSC through M\&A announcements

\begin{tabular}{ccllll}
\hline \hline Days & (C)AACSC (bps) & Wilcoxon & GRANK & $\%>0$ & $\mathrm{~N}$ \\
\hline-2 & 7.4437 & 0.2713 & 1.1602 & 51.0163 & 492 \\
-1 & 13.2771 & 0.7220 & 1.2129 & 49.5935 & 492 \\
0 & 165.1602 & $5.2137^{* * *}$ & $2.2618^{* *}$ & $58.1301^{* * *}$ & 492 \\
1 & 94.5582 & $3.1206^{* * *}$ & $1.7705^{*}$ & $55.2846^{* *}$ & 492 \\
2 & 29.4877 & $2.2604^{* *}$ & $1.7021^{*}$ & 53.2520 & 492 \\
\hline$[-2,2]$ & 309.9268 & $5.9471^{* * *}$ & $4.1933^{* * *}$ & $58.3333^{* * *}$ & 492 \\
{$[-2,1]$} & 280.4392 & $5.7833^{* * *}$ & $4.4270^{* * *}$ & $58.5366^{* * *}$ & 492 \\
{$[-2,0]$} & 185.8810 & $4.6087^{* * *}$ & $4.1949^{* * *}$ & $56.3008^{* * *}$ & 492 \\
{$[-1,2]$} & 302.4831 & $6.4476^{* * *}$ & $4.7968^{* * *}$ & $60.3659^{* * *}$ & 492 \\
{$[0,2]$} & 289.2061 & $6.2492^{* * *}$ & $5.1105^{* * *}$ & $59.7561^{* * *}$ & 492 \\
{$[-1,1]$} & 272.9954 & $6.2685^{* * *}$ & $5.0003^{* * *}$ & $61.3821^{* * *}$ & 492 \\
{$[-1,0]$} & 178.4372 & $5.2093^{* * *}$ & $4.7984^{* * *}$ & $58.9431^{* * *}$ & 492 \\
{$[0,1]$} & 259.7184 & $6.1462^{* * *}$ & $5.2279^{* * *}$ & $60.7724^{* * *}$ & 492 \\
{$[-5,5]$} & 364.8776 & $5.1754^{* * *}$ & $2.4374^{* *}$ & $58.3333^{* * *}$ & 492 \\
{$[-10,10]$} & 377.9458 & $3.9900^{* * * *}$ & $1.7106^{*}$ & $55.8943^{* *}$ & 492 \\
\hline \hline
\end{tabular}

The upper part of this table reports the average abnormal CDS spread changes (AACSC) for a symmetric event window period length of five days $([-2,2])$ around the announcement day $t_{0}$. The lower part shows the cumulative abnormal CDS spread changes (CAACSC) across different event windows. Both, the AACSC and the CAACSC are denoted in basis points. Wilcoxon indicates the test statistics of the Wilcoxon signed rank test and GRANK reports the statistics of the generalized rank test as described in Section 2. ' $\%>0$ ' is the percentage of positive (C)AACSC for a given day or event window. Significances are tested with Pearsons chi-squared test of equal proportions. $N$ is the number of observations.

*** $p<0.01,{ }^{* *} p<0.05, * p<0.10$

Figure 3: Cumulative average abnormal CDS spread changes ([-2,2])

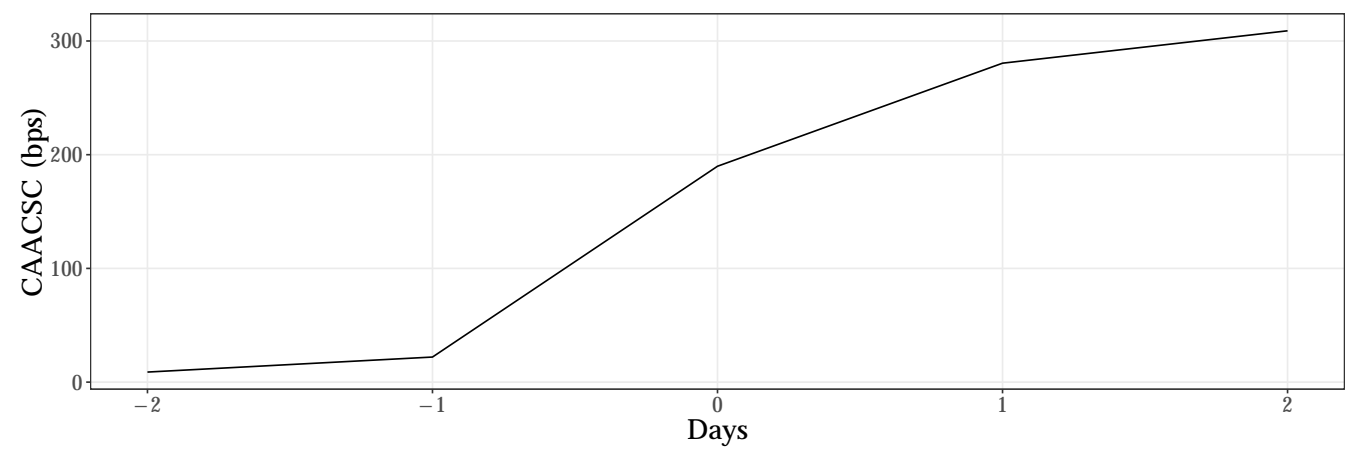

This figure shows the development of the cumulative average abnormal CDS spread changes (CAACSCs) within the main symmetric [-2,2] event window. 
Table 12: Sector analysis

\begin{tabular}{lcccccc}
\hline \hline & \multicolumn{2}{c}{ Acquirers } & \multicolumn{3}{c}{ Targets } \\
\hline & CAACSC $_{[-2,2]}(\mathrm{bps})$ & $\%>0$ & $\mathrm{~N}$ & CAACSC $_{[-2,2]}(\mathrm{bps})$ & $\%>0$ & $\mathrm{~N}$ \\
\hline Basic Materials & $562.6179^{* * *}$ & $65.0000^{*}$ & 40 & $868.0481^{* * *}$ & $69.2308^{* *}$ & 39 \\
Consumer Goods & $781.3939^{* * *}$ & $64.9123^{* *}$ & 57 & $737.1223^{* * *}$ & $64.2857^{* *}$ & 56 \\
Consumer Services & -52.6414 & 48.1481 & 54 & 27.6773 & 51.0638 & 47 \\
Energy & 234.5598 & 60.5263 & 38 & 177.5752 & 54.7619 & 42 \\
Financials & $241.1147^{*}$ & 60.0000 & 50 & 183.4476 & 54.1667 & 48 \\
Healthcare & $347.2396^{* * *}$ & 59.3220 & 59 & $221.5283^{* *}$ & 52.8571 & 70 \\
Industrials & $249.1793^{* *}$ & 54.1176 & 85 & $409.2263^{* * *}$ & $65.0794^{* *}$ & 63 \\
Technology & $191.1151^{* *}$ & 58.7302 & 63 & 49.8628 & 54.4304 & 79 \\
Telecommunication Services & $310.4738^{* *}$ & 68.0000 & 25 & $151.9998^{*}$ & 62.069 & 29 \\
Utilities & 278.2856 & 47.6190 & 21 & $534.2849^{*}$ & 63.1579 & 19 \\
\hline \hline
\end{tabular}

This table the shows cumulative changes of the five-day CDS spreads (CAACSC) across different sectors in basis points. The left part shows the cumulative abnormal CDS spread changes (CAACSC) according to the acquirers' Markit sectors, while the right part shows the CAACSC according to targets' Markit sectors. The significances of the CAACSCs are tested with the GRANK test. The difference between the CAACSCs is tested with the difference in means t-test. This test is implemented with the assumption of unequal variances when a test of equal variances is rejected at the $5 \%$ level and with the assumption of equal variances otherwise. ' $\%>0$ ' is the percentage of positive CAACSCs within the five-day event window. Significance is tested with Pearsons chi-squared test of equal proportions. $N$ is the number of observations.

*** $p<0.01, * * p<0.05, * p<0.10$ 
Table 13: Regional differences and model robustness

\begin{tabular}{lcccc}
\hline \hline & CAACSC $_{[-2,2]}(\mathrm{bps})$ & Difference $(\mathrm{bps})$ & $\%>0$ & $\mathrm{~N}$ \\
\hline Baseline & $309.9268^{* * *}$ & - & $58.3333^{* * *}$ & 492 \\
Europe & $296.4429^{* * *}$ & 13.4839 & 55.4913 & 173 \\
North America & $317.2394^{* * *}$ & -7.3126 & $59.8746^{* * *}$ & 319 \\
Market model & $311.9540^{* * *}$ & -2.0272 & $59.3496^{* * *}$ & 492 \\
Constant mean model & $295.7186^{* * *}$ & 14.2082 & $58.9431^{* * *}$ & 492 \\
60 days estimation window & $310.0649^{* * *}$ & -0.1381 & $58.7398^{* * *}$ & 492 \\
200 days estimation window & $322.3100^{* * *}$ & -12.3832 & $60.1790^{* * *}$ & 447 \\
Without gap & $307.4706^{* * *}$ & 2.4562 & $58.9431^{* * *}$ & 492 \\
Without rating adjustment & $308.2417^{* * *}$ & 1.6851 & $57.9268^{* * *}$ & 492 \\
\hline \hline
\end{tabular}

This table shows the cumulative average abnormal CDS spread change within the [-2,2] main event window during different robustness tests. Baseline is the result from our main analysis as reported in Table 11 (Section 4.1). Europe and North America control for the robustness of our results for the two analyzed regions separately. Market model is a robustness check where the four factor model from our main analysis is substituted by a one factor model. The factor used is the respective CDS index as described in Section 2. Constant mean model substitutes the four factor model by a constant mean model where the CDS spead of a respective firm is estimated as the mean CDS spread of the estimation window. The 60 days estimation window and 200 days estimation window robustness tests vary the length of the estimation window to 60 and 200 days, respectively. As we model a gap between the estimation and event window for our main analysis, we allow for a implementation without a gap between the estimation and event window in the Without gap robustness check. The Without rating adjustment test implements that only the investment grade index is used to predict the returns from the four factor model. The first column reports the cumulative average abnormal CDS spread changes (CAACSC) in basis points. The significance of the CAACSC is tested with the GRANK test. Difference (bps) shows the difference between CAACSC from respective robustness checks and those from the baseline analysis. The difference between the CAACSC is tested with the difference in means t-test. This test is implemented with the assumption of unequal variances when a test of equal variances is rejected at the $5 \%$ level, and with the assumption of equal variances otherwise. ' $\%>0$ ' is the percentage of positive CAACSC in the $[-2,2]$ event window. The significance is tested with Pearsons chi-squared test of equal proportions. Finally, $N$ is the number of observations.

${ }^{* * *} p<0.01,{ }^{* *} p<0.05,{ }^{*} p<0.10$ 
Table 14: Deal characteristics

\begin{tabular}{|c|c|c|c|}
\hline & $\mathrm{CAACSC}_{[-2,2]}(\mathrm{bps})$ & $\%>0$ & $\mathrm{~N}$ \\
\hline \multicolumn{4}{|c|}{ Panel A: Diversification } \\
\hline \multicolumn{4}{|c|}{$\begin{array}{l}\text { Grouped by whether Markit sector classification of the } \\
\text { acquirer and the target is the same }\end{array}$} \\
\hline No Diversification & $310.6576^{* * *}$ & $60.2703^{* * *}$ & 370 \\
\hline Diversification & $307.7107^{* *}$ & 52.459 & 122 \\
\hline Difference & 2.9469 & & \\
\hline \multicolumn{4}{|c|}{ Panel B: Type of transaction } \\
\hline \multicolumn{4}{|c|}{ Grouped by whether the deal type is a merger } \\
\hline Merger & $347.4215^{* * *}$ & $60.2906^{* * *}$ & 413 \\
\hline Acquisition of assets & 113.9104 & 48.1013 & 79 \\
\hline Difference & $233.5111^{* *}$ & & \\
\hline
\end{tabular}

Panel C: Cross-border

Grouped by whether the target firm is located in a different country

\begin{tabular}{lccc} 
Cross-border & $296.8758^{* * *}$ & $60.5839^{* * *}$ & 274 \\
Domestic & $326.3304^{* * *}$ & 55.5046 & 218 \\
Difference & -29.4546 & & \\
\hline
\end{tabular}

Panel D: Complexity of the transaction

(i) Grouped by transaction volume

$\begin{array}{lccc}\text { Above median } & 598.5933^{* * *} & 68.2927^{* * *} & 246 \\ \text { Below median } & 21.2604 & 48.374 & 246 \\ \text { Difference } & 577.3329^{* * *} & & \end{array}$

(ii) Grouped by transaction volume ratio

$\begin{array}{lccc}\text { Above median } & 579.5838^{* * *} & 68.018^{* * *} & 222 \\ \text { Below median } & 37.6387 & 47.5113 & 221 \\ \text { Difference } & 541.9451^{* * *} & & \end{array}$

(iii) Grouped by size ratio

\begin{tabular}{lccc} 
Above median & $421.896^{* *}$ & $60.6897^{* *}$ & 145 \\
Below median & $213.0145^{* *}$ & 54.4828 & 145 \\
Difference & $208.8815^{*}$ & & \\
\hline
\end{tabular}

This table shows cumulative average abnormal CDS spread changes (CAACSC) of the fiveday main event window across different deal characteristics in basis points. The description of the deal characteristics is provided in Table 9. The significance of the cumulative abnormal CDS spread changes (CAACSC) is tested with the GRANK test. The differences between CAACSC are tested with the difference in means t-test. This test is implemented with the assumption of unequal variances when a test of equal variances is rejected at the $5 \%$ level, and with the assumption of equal variances otherwise. ' $\%>0$ ' is the percentage of positive CAACSC in the five-day event window. Significance is tested with Pearsons chi-squared test of equal proportions. $N$ is the number of observations.

*** $p<0.01,{ }^{* *} p<0.05,{ }^{*} p<0.10$ 
Table 15: Acquirer characteristics

\begin{tabular}{lccc}
\hline \hline & CAACSC $_{[-2,2]}(\mathrm{bps})$ & $\%>0$ & $\mathrm{~N}$ \\
\hline Panel A: Size & & & \\
Grouped by total assets & & & \\
Above median & $191.297^{* * *}$ & 53.1532 & 222 \\
Below median & $427.6824^{* * *}$ & $62.4434^{* * *}$ & 221 \\
Difference & $-236.3854^{* *}$ & & \\
\hline
\end{tabular}

Panel B: Leverage

(i) Grouped by leverage ratio

\begin{tabular}{lccc} 
Above median & $345.584^{* * *}$ & $60.6481^{* * *}$ & 216 \\
Below median & $292.5921^{* * *}$ & $56.4815^{*}$ & 216 \\
Difference & 52.9919 & & \\
\hline
\end{tabular}

(ii) Grouped by whether the acquirer's leverage is lower than the target's

$\begin{array}{llrr}\text { Lower acquirer leverage } & 746.0231^{* * *} & 69.3878^{* * *} & 98 \\ \text { Higher acquirer leverage } & 198.3355^{* * *} & 59.8592^{* *} & 142 \\ \text { Difference } & 547.6876^{* * *} & & \end{array}$

(iii) Grouped by leverage change

\begin{tabular}{lccc} 
Above median & $437.4482^{* * *}$ & $60.5769^{* * *}$ & 208 \\
Below median & $220.2224^{* * *}$ & 55.7692 & 208 \\
Difference & $217.2258^{*}$ & & \\
\hline
\end{tabular}

Panel C: Valuation

Grouped by market-to-book value

\begin{tabular}{lccc} 
Above median & $317.9047^{* * *}$ & $60.7595^{* * *}$ & 237 \\
Below median & $318.8936^{* * *}$ & $56.962^{* *}$ & 237 \\
Difference & -0.9889 & & \\
\hline
\end{tabular}

Panel D: Risk

(i) Grouped by rating categories

$\begin{array}{lccr}\text { Investment grade } & 314.0083^{* * *} & 58.8101^{* * *} & 437 \\ \text { Speculative grade } & 277.4977 & 54.5455 & 55 \\ \text { Difference } & 36.5106 & & \end{array}$

(ii) Grouped by mean CDS spread

\begin{tabular}{lccc} 
Above median & $218.945^{* * *}$ & $55.6911^{*}$ & 246 \\
Below median & $400.9087^{* * *}$ & $60.9756^{* * *}$ & 246 \\
Difference & $-181.9637^{*}$ & & \\
\hline
\end{tabular}


Table 15: Acquirer characteristics (continued)

\begin{tabular}{|c|c|c|c|}
\hline & $\mathrm{CAACSC}_{[-2,2]}(\mathrm{bps})$ & $\%>0$ & $\mathrm{~N}$ \\
\hline \multicolumn{4}{|l|}{ Panel E: Regulation } \\
\hline \multicolumn{4}{|c|}{ Grouped by regulated sectors } \\
\hline High-regulated sectors & $245.9909^{*}$ & 57.7982 & 109 \\
\hline Unregulated sectors & $328.1227^{* * *}$ & $58.4856^{* * *}$ & 383 \\
\hline Difference & -82.1318 & & \\
\hline
\end{tabular}

This table shows cumulative average abnormal CDS spread changes (CAACSC) of the five-day main event window across different acquirer characteristics in basis points. The description of the acquirer characteristics is provided in Table 9. The significance of the cumulative abnormal CDS spread changes (CAACSC) is tested with the GRANK test. The differences between CAACSC are tested with the difference in means t-test. This test is implemented with the assumption of unequal variances when a test of equal variances is rejected at the $5 \%$ level, and with the assumption of equal variances otherwise. ' $\%>0$ ' is the percentage of positive CAACSC in the five-day event window. Significance is tested with Pearsons chi-squared test of equal proportions. $N$ is the number of observations.

*** $p<0.01,{ }^{* *} p<0.05,{ }^{*} p<0.10$ 
Table 16: Target characteristics

\begin{tabular}{|c|c|c|c|}
\hline & $\mathrm{CAACSC}_{[-2,2]}(\mathrm{bps})$ & $\%>0$ & $\mathrm{~N}$ \\
\hline \multicolumn{4}{|l|}{ Panel A: Size } \\
\hline \multicolumn{4}{|c|}{ Grouped by total assets } \\
\hline Above median & $399.4556^{* * *}$ & $61.3497^{* * *}$ & 163 \\
\hline Below median & $258.652^{* * *}$ & 55.2147 & 163 \\
\hline Difference & 140.8036 & & \\
\hline \multicolumn{4}{|c|}{ Panel B: Leverage } \\
\hline \multicolumn{4}{|c|}{ Grouped by leverage ratio } \\
\hline Above median & $542.1753^{* * *}$ & $65.4135^{* * *}$ & 133 \\
\hline Below median & $301.473^{* * *}$ & $62.1212^{* * *}$ & 132 \\
\hline Difference & 240.7023 & & \\
\hline \multicolumn{4}{|c|}{ Panel C: Valuation } \\
\hline \multicolumn{4}{|c|}{ Grouped by market-to-book value } \\
\hline Above median & $512.0164^{* * *}$ & $64.6341^{* * *}$ & 164 \\
\hline Below median & $133.4471^{* *}$ & 56.0976 & 164 \\
\hline Difference & $378.5693^{* * *}$ & & \\
\hline
\end{tabular}

Panel D: Risk

(i) Grouped by rating categories

Investment grade $\quad 571.9959 * * * \quad 65.0794 * * \quad 63$

Speculative grade $\quad 803.5999^{* * *} \quad 73.6842^{* * *} \quad 57$

Difference $\quad-231.604$

(ii) Grouped by whether the target is rated

\begin{tabular}{llcl} 
Rated & $682.0078^{* * *}$ & $69.1667^{* * *}$ & 120 \\
Unrated & $189.9007^{* * *}$ & $54.8387^{*}$ & 372 \\
Difference & $492.1071^{* * *}$ & & \\
\hline
\end{tabular}

Panel E: Publicly listed

Grouped by listing status

\begin{tabular}{lccc} 
Listed & $332.5667^{* * *}$ & $60.7143^{* * *}$ & 392 \\
Private & $221.1787^{* *}$ & 49.0000 & 100 \\
Difference & 111.388 & & \\
\hline
\end{tabular}

This table shows cumulative average abnormal CDS spread changes (CAACSC) of the five-day main event window across different target characteristics in basis points. The description of the target characteristics is provided in Table 9. The significance of the cumulative abnormal CDS spread changes (CAACSC) is tested with the GRANK test. The differences between CAACSC are tested with the difference in means ttest. This test is implemented with the assumption of unequal variances when a test of equal variances is rejected at the $5 \%$ level, and with the assumption of equal variances otherwise. ' $\%>0$ ' is the percentage of positive CAACSC in the fiveday event window. Significance is tested with Pearsons chi-squared test of equal proportions. $N$ is the number of observations.

*** $p<0.01,{ }^{* *} p<0.05,{ }^{*} p<0.10$ 